\title{
Speleothems in quartz-sandstone caves of Ponta Grossa municipality, Campos Gerais region, Paraná state, southern Brazil
}

\author{
Henrique S. Pontes (D) ${ }^{1,2^{*}}$, Luiz A. Fernandes (D) ${ }^{3}$, Mário S. de Melo (D) ${ }^{1}$, \\ Gilson B. Guimarães (1) 1,2, and Laís L. Massuqueto (1) ${ }^{3,2}$ \\ ${ }^{1}$ Geoscience Department, Ponta Grossa State University (UEPG), Av. General Carlos Cavalcanti, 4748, Ponta Grossa, Brazil \\ ${ }^{2}$ University Group of Speleological Research (GUPE), St. São Romulo, 375, Ponta Grossa, Brazil \\ ${ }^{3}$ Federal University of Paraná (UFPR), Av. Cel. Francisco H. dos Santos, 100, Curitiba, Brazil
}

\begin{abstract}
The present communication characterizes and discusses the genesis of cave speleothems developed in Furnas Formation (Silurian-Devonian) and Vila Velha sub-unit (Campo Mourão Formation, Upper Carboniferous) quartz-sandstones, in southern Brazil. The research, which involved stratigraphic and petrographic studies, was conducted to identify the faciological context of occurrence of these features, and to determine, through different analytical methods, their mineralogical composition and porosity, and also the action of microbial markers on the genesis of these secondary mineral deposits. The speleothems were classified into six types based on form, composition and genesis: (1) arborescent (coral), (2) mushroom-shaped, (3) stalactitic, (4) stalagmitic, (5) columnar with horizontal/ascending growth, and (6) fibrous. In response to substrate permoporosity, speleothems develop on all sandstone facies of the study area, mainly in sites controlled by bedding, stratification and fracturing planes. They are less frequent, however, in conglomerate and silty-clayey layers of the Furnas Formation, being composed mainly of silica (opal-A and cryptocrystalline silica) and kaolinite, with lesser contribution of gypsum and amorphous iron oxides associated with goethite and hematite. Detritic minerals such as quartz and muscovite also take part in the composition of these features. Plant and invertebrate fragments were identified, including biosignatures and microorganisms capable of favoring precipitation of silica (possibly cyanobacteria and diatom) and iron oxide (possibly Gallionella ferruginea). Such biosignatures and extracellular polymeric substances (biofilms) associated with speleothems are evidence of organomineralization, also known as biologically induced mineralization. The results, which indicate biological action on the genesis of speleothems, raise further discussion on the influence of microorganisms on the dissolution and precipitation of silica and kaolinite in the region.
\end{abstract}

Keywords: microbialites, non-carbonate rock caves, microorganisms, Furnas Formation, Vila Velha Sandstone, speleothems

Received 13 February 2020; Revised 2 June 2020; Accepted 3 June 2020

Citation: $\quad$ Pontes H.S., Fernandes L.A., Melo M.S., Guimarães G.B., and Massuqueto L.L., 2020. Speleothems in quartz-sandstone caves of Ponta Grossa municipality, Campos Gerais region, Paraná state, southern Brazil. International Journal of Speleology, 49 (2), 119-136. Tampa, FL (USA) ISSN 0392-6672 https://doi.org/10.5038/1827-806X.49.2.2313

\section{INTRODUCTION}

Chemical weathering is a determining factor to the development of relief forms in karst systems. Through chemical processes such as hydration, dissolution, hydrolysis and oxidation, ions and molecules are removed from the surfaces of mineral components, allowing thus the formation of secondary porosity by karstification, with partial or total removal of constituents (Dubois et al., 2014). In both cases, removal and transportation of ions and molecules creates cavities and speleothems, the latter corresponding to secondary chemical deposits.

Such geological features usually form in underground environments, but they are also found in superficial portions of karst systems, such as cavities on rock walls. However, there are reports of speleothems in areas subject to chemical weathering and mineral precipitation in caves or surface walls where karst relief is absent, as are granite (e.g., Vidal Romani \& Rodriguez, 2007) and basalt (e.g., Miller et al., 2014; Gonzalez-Pimentel et al., 2018) outcropping areas. 
Being unexclusive of karst systems, speleothems are not restricted to carbonate rocks. The development of these features is perfectly possible in rocks of low solubility, as are those of siliciclastic composition like quartz-sandstones and quartzites. In fact, several non-carbonate karst systems around the world are located in quartzites and quartz-sandstones with features, shapes, spatial organization and functioning characteristic of karst areas, as reported by Wray $\&$ Sauro (2017).

Several karst occurrences in Brazil are found in siliciclastic rocks whose dissolution features include speleothems. Main examples are quartzites of the Itacolomi Group in the State of Minas Gerais (Renó et al., 2009), quartz-sandstones of the Chapada dos Guimarães plateau in the State of Mato Grosso, and Serra de Itaqueri, State of São Paulo (Hardt et al., 2009), sandstone caves in the State of Tocantins (Morais \& Souza, 2009), and quartzite caves along the Serra do Ibitipoca range, State of Minas Gerais (Corrêa Neto \& Baptista Filho, 1997; Willens et al., 2008). One of the most notable examples of karst in siliceous rocks is located in South America, in the Tepuis of southeastern Venezuela, where gigantic cave systems include siliceous speleothems of large dimensions, diversity and rarity (White et al., 1966; Urbani, 1990; Galan \& Lagarde, 1988; Aubrecht et al., 2012; Sauro, 2014; Sauro et al., 2018, 2019; Auler \& Sauro, 2019).

In non-carbonate cemented quartz-sandstones of Furnas Formation and Vila Velha Sub-unit terrains in southern Brazil, karstification involves dissolution of quartz and other mineral components. These rocks host hundreds of caves, dolines, underground drainage systems with sinks and springs, among other geological features typical of karst relief i.e., arenized/ phantomized rocks, ceiling and wall channels, dissolution ducts, domes, and alveoli.

Speleothems are also present in these units, mainly inside caves. Several authors report such deposits in Furnas Formation, among whom Spinardi and Lopes (1990), Budny (2004), Melo and Giannini (2007), Pontes et al. (2008), Melo (2010), Pontes (2010, 2014), Massuqueto (2010), Melo et al. (2011, 2015), Hardt (2011), and Flügel Filho (2012). Few mentions are made of the such deposits in Vila Velha sandstones, though. Melo (2006), Letenski et al. (2009) and Letenski et al. (2011) mention microspeleothems that occur at surface level. Pontes et al. (2012) report a set of speleothems up to $15 \mathrm{~cm}$ long in an underground cavity in the same rocks.

Quartz-sandstone speleothems exhibit, in most cases, characteristics that are different from those developed in carbonate rocks. In abundance and size, they are usually smaller compared to their carbonate counterparts. However, secondary chemical deposits in quartz-sandstones are among the most intriguing geological features, mainly due to their composition and genesis.

Flügel Filho et al. (2012) and Flügel Filho (2012) present a preliminary morphological classification for speleothems developed on Furnas Formation rocks.
Melo et al. (2015) point out a siliceous composition revealed by Energy-dispersive X-ray Spectrometry (EDS). The study carried out by Melo et al. (2015) is the only one to present the chemical analysis of these secondary mineral deposits in rocks of the Furnas Formation, which does not correspond, however, to the speleothems presented here. Studies on speleothems of the Vila Velha Sub-unit have not yet been performed.

Information gaps regarding secondary chemical deposits in Furnas Formation and Vila Velha Subunit quartz-sandstones would justify detailed studies involving microscopy, chemical and petrographic analysis, and stratigraphic surveying to identify possible correlations between the development of such features and the faciological and diagenetic characteristics of the sandstones. The present study aims to characterize cave speleothems developed in both geological units, discussing the genesis of these features and the possible influence of microorganisms on quartz and kaolinitic cement dissolution and precipitation of secondary minerals as well.

\section{STUDY AREA}

The research was conducted on data from underground cavities found in Furnas Formation (Silurian-Devonian) and Vila Velha Sandstone rocks, the latter a sub-unit of the Campo Mourão Formation (Carboniferous-Permian) in the eastern border of the Paraná Basin, in Ponta Grossa municipality, State of Paraná, southern Brazil (Fig. 1).

One hundred and ten caves are found in the study area, 106 of which in rocks of the Furnas Formation, and four in Vila Velha sandstones, along with hundreds of dolines and sinks, springs, underground rivers, erosive features (speleogens) and arenized/ phantomized rocks, all of them typical of karst relief. In non-carbonate quartz-sandstones, karstification process involves dissolution of kaolinitic cement and quartz grains, as highlighted by Pontes (2010) and Melo et al. (2011, 2015).

The regional climate is identified as Subtropical $\mathrm{Cfb}$ in Köppen's classification, corresponding to mild temperate conditions with average temperature below $18^{\circ} \mathrm{C}$ in the coldest month and below $22^{\circ} \mathrm{C}$ in the hottest month. Summers are cool, with no definite dry season. Rainfall is well distributed, with average annual rainfall between 1,400 and 1,800 mm, and average relative humidity between 75 and $80 \%$ according to Cruz (2007). It is worth mentioning the presence, in the eastern borders of the study area, of the topographic step represented by Devonian Escarpment delimiting the first two plateaus of Paraná and whose altitude differences, of up to $300 \mathrm{~m}$ at some points, allow for a localized increase in precipitation and air humidity.

\section{GEOLOGICAL ASPECTS}

Terrains including mostly quartz-sandstones of the Furnas Formation (Paraná Group) and the Vila Velha Sub-unit of the Campo Mourão Formation (Itararé 


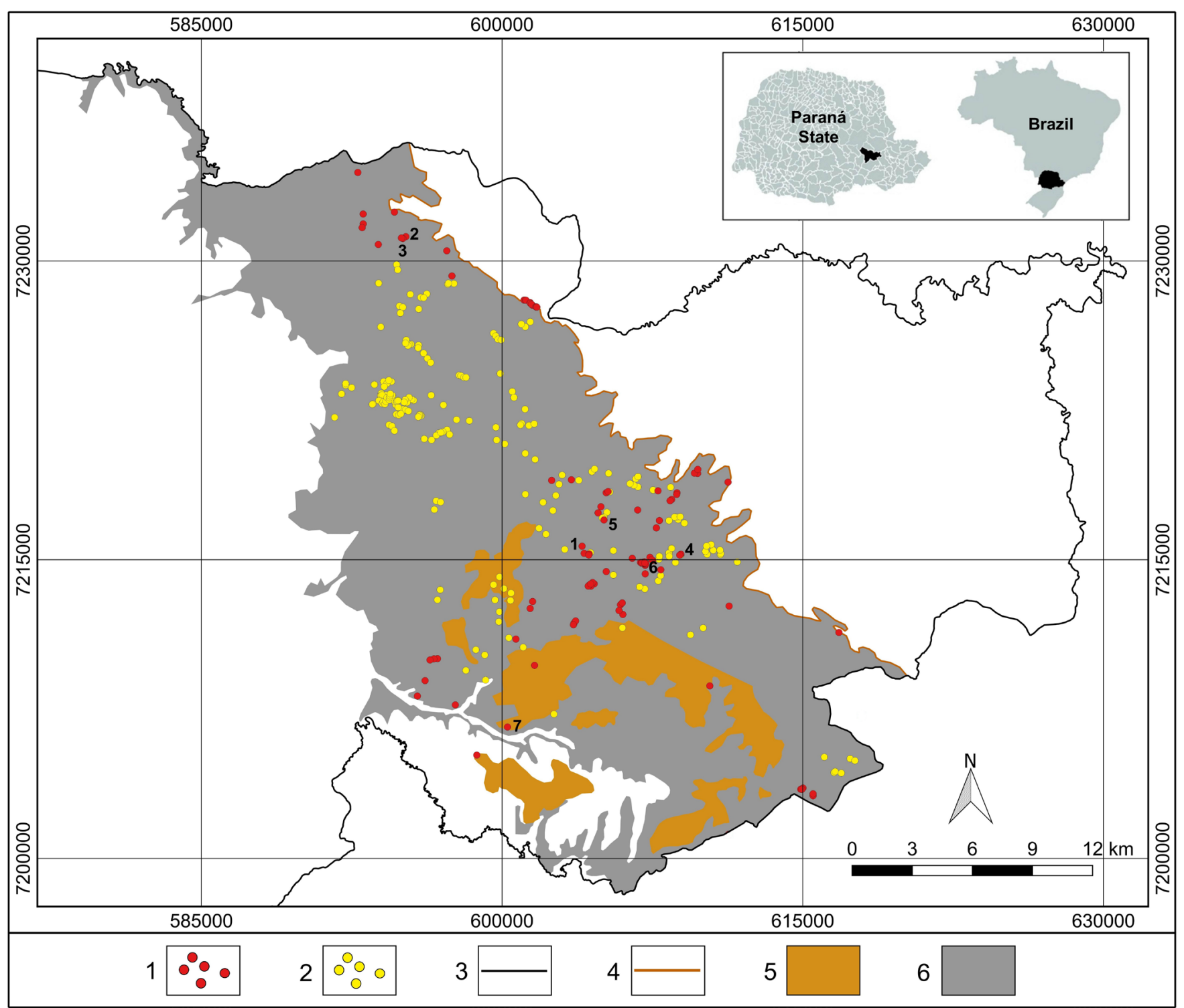

Fig. 1. Location of the study area. Cartographic conventions: (1) caves; (2) dolines; (3) municipal limits of Ponta Grossa; (4) Devonian Scarpment; (5) outcrop area of the Itararé Group including the Vila Velha Sandstone sub-unit; (6) outcropping area of the Furnas Formation. Numbers indicate caves from which samples were collected: (1) Furna do Buraco do Padre; (2) Caverna da Chaminé; (3) Gruta da Inspirada;

(4) Caverna do Zé; (5) Sumidouro do Córrego das Fendas; (6) Fenda Sem Fim; (7) Gruta Andorinhas da Pedra Suspensa.

Group) extend for approximately 85 and $15 \%$ of the total study area, respectively.

The Furnas Formation sediments are SilurianDevonian in age, dating between 421 and $395 \mathrm{Ma}$ (Borghi, 1993; Assine, 1999; Milani et al., 2007). They consist mainly of medium to coarse quartz-sandstones cemented by kaolinite and illite (Assine, 1996; Melo \& Giannini, 2007 and Milani et al., 2007). The sandstones bear plane-parallel and cross-stratifications and, commonly, decimetric intercalations of silt and clay. At the base of the formation, conglomerate layers exceed one meter thick.

According to Assine (1996), the sandstones occur in tabular, lenticular and cuneiform strata with thickness between 0.5 to $5 \mathrm{~m}$ and marked crossstratification. The same author proposes a subdivision of Furnas Formation in three, Lower, Middle and Upper units. Another stratigraphic classification is proposed by Lobato \& Borghi (2005), according to which the formation is compartmentalized into four units, the Interval II of Assine (1996) being individualized as two segments, A and B. According to Assine (1996) the Furnas Formation is about $250 \mathrm{~m}$ thickness.
Bergamaschi (1992), Assine et al. (1994) and Assine (1996) suggest deposition of the Furnas Formation under deltaic and platformal conditions. However, much remains to be discussed on the deposition of these units, especially regarding the lower conglomeratic section, which is totally devoid of fossils (Milani et al., 2007). Some authors argue that the deposition of the Furnas Formation occurred in anastomosed river systems (Schneider et al., 1974; Zalán et al., 1987) or in a large braided river system (Pavan, 2015; Araújo, 2016).

The Vila Velha Sandstone lies concordantly over diamictites, glacial rhythmites and argilites of the Campo Mourão Formation. The sub-unit consists essentially of fine to coarse reddish sand grains welded by a ferruginous cement, with varying degrees of sorting, and the presence of pebbles at the base. Maack (1946) identifies quartz, partially kaolinized feldspar, muscovite, chlorite and garnet among the mineral constituents of the formation. Melo and Coimbra (1996) and Melo et al. (2007) point out, however, that these minerals occur in layers below the sandstones that known for the typical relief of 
the Vila Velha region. The latter unit would consist only of quartz-sandstones with a reduced amount of polycrystalline grains (quartzite) and fragments of sandy mudstones forming a pseudomatrix that resulted from deformation and crushing.

Schneider et al. (1974) compartmentalize the Itararé Group in the Campo do Tenente, Mafra and Rio do Sul formations. França and Potter (1988) propose another division in which the unit includes the Lagoa Azul, Campo Mourão and Taciba formations, this being the classification adopted for the present study.

Maack (1946), Melo and Coimbra (1996), França et al. (1996), and Melo et al. (2007) report incipient plane-parallel stratification in these sandstones, which are normally massive with low-angle crossstratification, wavy marks and clayey intraclasts. According to França et al. (1996), the sandstones exhibit the well-known ruiniform relief of the Vila Velha region, consisting in layers more than $30 \mathrm{~m}$ thick and hundreds to more than a thousand meters wide. For Melo et al. (2007), the thickness of Vila Velha Sandstone layers is of the order of $50 \mathrm{~m}$, whereas for Maack (1946) it corresponds to $65 \mathrm{~m}$. Vesely (2011) includes an additional 30-m thick arenitic interval, referred to as the Basal Sandstone.

According to Milani et al. (1994), the rocks comprised in the Itararé Group were deposited in fluvioglacial, marine-glacial and marine environments. França et al. (1996) consider the Vila Velha sandstones as deposited in the form of subaqueous lobes under dense gravitational flows initiated at basal parts glaciers. The occurrence of low-angle cross-stratification and vertical and horizontal perforations indicates shallow marine sedimentation influenced by tides (Canuto et al., 1997). Vesely (2011) identifies grooves and glacial ridges in the stratigraphic succession of the Vila Velha Sandstone, suggesting glacier displacement over unconsolidated sediments, which is characteristic of proglacial environments.

An Upper Carboniferous age is attributed to The Vila Velha Sandstone based on the fossil content of shales that occur interspersed with sediments of other Campo Mourão Formation sub-unit, the Lapa Sandstone, and correlations with rocks of the Lagoa Azul Formation (Milani et al., 1994).

The relief in exposed areas of Furnas and Vila Velha rocks is markedly controlled by tectonic structures associated with canyons and crevices along two main directions. According to Zalán et al. (1990), these structures resulted from the uplift of the Ponta Grossa Arch (NW-SE) and reactivation of Proterozoic basement terrains (NE-SW) by crustal arching during the Mesozoic. Such tectonic structures facilitate weathering and the erosive action of water at surface and underground environments, which makes such discontinuities preferred zones for the development of underground ducts and galleries.

\section{METHODS}

Surveying consisted in fieldwork to collect information on lithotypes, preparation of geological sections, and identification of speleothems in underground cavities and rocky walls. Occurrences of these secondary chemical deposits were identified against an inventory of geodiversity compiled for cavities of the study area by Pontes et al. (2018a, b). Laboratory work included stratigraphic interpretation, petrographic interpretation, faciological characterization, and chemical analysis.

A tentative correlation between the speleothems and stratigraphic and lithological characteristics of the sandstones is drawn based on geological sections of occurrence sites. Six attributes were considered: (1) mineralogical composition and textural parameters (grain size and sorting), (2) porosity, (3) sedimentary structures, (4) tectonic structures, (5) weathering features (arenization/phantomization), and (6) pattern of occurrence.

Different analytical methods were applied to characterize the speleothems (Table 1). In order to determine their internal structures and to identify their distinct components, especially those of biological origin, Transmitted Light Microscopy (Leica DMLP, with polarizers and digital image capture) was initially applied, at Federal University of Paraná facilities, followed by Scanning Electron Microscopy (SEM). Total porosity values were interpreted from Computed Microtomography (micro-CT) images obtained with Skyscan 1172 equipment at $88 \mathrm{kV}$ of voltage and $112 \mu \mathrm{A}$ of current intensity at the Laboratory of Minerals and Rocks (LAMIR) of the same university. The Skyscan CTVox software version 1.5 performs an automatic count of the black pixels (interpreted as pores) of the micro-CT binary images, providing a mathematical estimate of the total porosity of the material.

In order to identify a possible contribution of microorganisms to the genesis of the secondary deposits, SEM was applied, with Tescan VEGA3 equipment at the Electron Microscopy Center (CME) of the Federal University of Paraná (UFPR) and Shimadzu SSX-550 equipment at the Multi-User Laboratory Complex (CLabmu) of the Ponta Grossa State University (UEPG). In both cases, the voltage used was $15 \mathrm{kV}$. At that research stage, physical (form) and chemical (composition) similarities between the observed speleothems and those of the largest cavities in Precambrian sandstones of the Venezuelan Tepuis were drawn. As Aubrecht et al. (2008) and Lundberg et al. (2010) point out, the Tepuis speleothems, which correspond to microbialites or biospeleothems, were formed under the influence of microorganisms.

For control and identification of the chemical elements present in the samples that were subject to SEM, Energy-dispersive Spectrometry (EDS) was applied with tools coupled to the microscopes. The chemical composition of the speleothems, in turn, was determined by Powder X-ray Diffractometry (XRD) with a D8 Advance DaVinci Bruker diffractometer (CuKalfa, $40 \mathrm{kV}, 40 \mathrm{~mA}, 3$ to 70 degrees $2 \Theta$ ) at the X-ray Diffraction Laboratory of the Geosciences Institute, University of São Paulo (USP).

Four samples of speleothems developed in Vila Velha sandstones were analyzed, all from a cave known 
Table 1. Samples, performed analyses, and collection sites. Samples highlighted in gray are from Formação Furnas whereas the orange ones from Vila Velha Sandstone.

\begin{tabular}{|c|c|c|c|c|c|}
\hline & Identification & Material & Analysis & Collection site & Color \\
\hline 1 & BP-01 & mushroom-shaped speleothem & XRD & Cave, entrance area & white/gray \\
\hline 2 & BP-02 & mushroom-shaped speleothem & SEM/EDS & Cave, entrance area & white/gray \\
\hline 3 & $\mathrm{CC}-01$ & arborescent speleothem & Petrographic Microscopy & Cave, twilight area & gray/brown \\
\hline 4 & $\mathrm{CC}-02$ & stalactitic speleothem & Petrographic Microscopy & Cave, twilight area & gray/brown \\
\hline 5 & CC-03 & stalactitic speleothem & SEM/EDS & Cave, twilight area & gray/brown \\
\hline 6 & $\mathrm{CC}-04$ & arborescent speleothem & Petrographic Microscopy & Cave, twilight area & gray/brown \\
\hline 7 & $\mathrm{CC}-05$ & arborescent speleothem & Petrographic Microscopy & Cave, twilight area & gray/brown \\
\hline 8 & CC-06 & arborescent speleothem & SEM/EDS & Cave, twilight area & gray/brown \\
\hline 9 & CZ-01-A & stalagmitic speleothem & Petrographic Microscopy & Cave, dark area & red/yellow \\
\hline 10 & CZ-01-B & stalagmitic speleothem & SEM/EDS & Cave, dark area & red/yellow \\
\hline 11 & GI-01 & arborescent speleothem & SEM/EDS/XRD & Cave, dark area & \\
\hline 12 & SCF-01 & $\begin{array}{c}\text { columnar speleothem with } \\
\text { horizontal/ascending growth }\end{array}$ & SEM/EDS/XRD & Cave, dark area & brown/white \\
\hline 13 & $\mathrm{SCF}-02$ & $\begin{array}{l}\text { columnar speleothem with } \\
\text { horizontal/ascending growth }\end{array}$ & Petrographic Microscopy & Cave, dark area & brown/white \\
\hline 14 & SCF-03-A & $\begin{array}{l}\text { columnar speleothem with } \\
\text { horizontal/ascending growth }\end{array}$ & Micro-CT & Cave, dark area & brown/white \\
\hline 15 & SCF-03-B & $\begin{array}{l}\text { columnar speleothem with } \\
\text { horizontal/ascending growth }\end{array}$ & Petrographic Microscopy & Cave, dark area & brown/white \\
\hline 16 & $\mathrm{SCF}-04$ & mushroom-shaped speleothem & SEM/EDS & Cave, dark area & white/gray \\
\hline 17 & SCF-05 & rimstone (micro gours) & SEM/EDS & Cave, dark area & brown/red \\
\hline 18 & FSF & fibrous speleothem & XRD & Cave, dark area & yellow/white \\
\hline 1 & GAPS-01-A & arborescent speleothem & $\begin{array}{l}\text { Petrographic Microscopy/ } \\
\text { Micro-CT/XRD }\end{array}$ & Cave, entrance area & gray/brown \\
\hline 2 & GAPS-01-B & arborescent speleothem & SEM/EDS & Cave, entrance area & gray/brown \\
\hline 3 & GAPS-02-A & mushroom-shaped speleothem & XRD & Cave, entrance area & gray/white \\
\hline 4 & GAPS-02-B & mushroom-shaped speleothem & SEM/EDS & Cave, entrance area & gray/white \\
\hline
\end{tabular}

as Gruta Andorinhas da Pedra Suspensa, located within a protection area in the State of Paraná, the Vila Velha State Park (Fig. 1). Specific studies were carried out on 18 samples of secondary chemical deposits from Furnas sandstones, among which rimstones (microterraces or micro-gours) that are not characterized as speleothems in the study area. The collection points at Furnas Formation outcrops are all located within the Campos Gerais National Park, in the following caves: Furna do Buraco do Padre, Caverna da Chaminé, Gruta da Inspirada, Caverna do Zé, Sumidouro do Córrego das Fendas, and Fenda Sem Fim (Fig. 1).

\section{RESULTS}

\section{Classification}

Speleothems occur in nearly all underground cavities found in the study area, along with alveoli, recesses and ducts in surface cavities. Six varieties of speleothems have been defined upon revision of the classification presented by Flügel Filho et al. (2012) and Flügel Filho (2012): a) arborescent (coral), b) mushroom-shaped, c) stalactitic, d) stalagmitic, e) columnar with horizontal/ascending growth, and f) fibrous (Fig. 2 and Fig. 3). Although small in size compared to those developed on carbonate rocks, and ranging between a few millimeters and 15 centimeters in length, the speleothems of the study area are abundant and easily found. Of reduced dimensions, the rare fibrous speleothems present are exceptions.

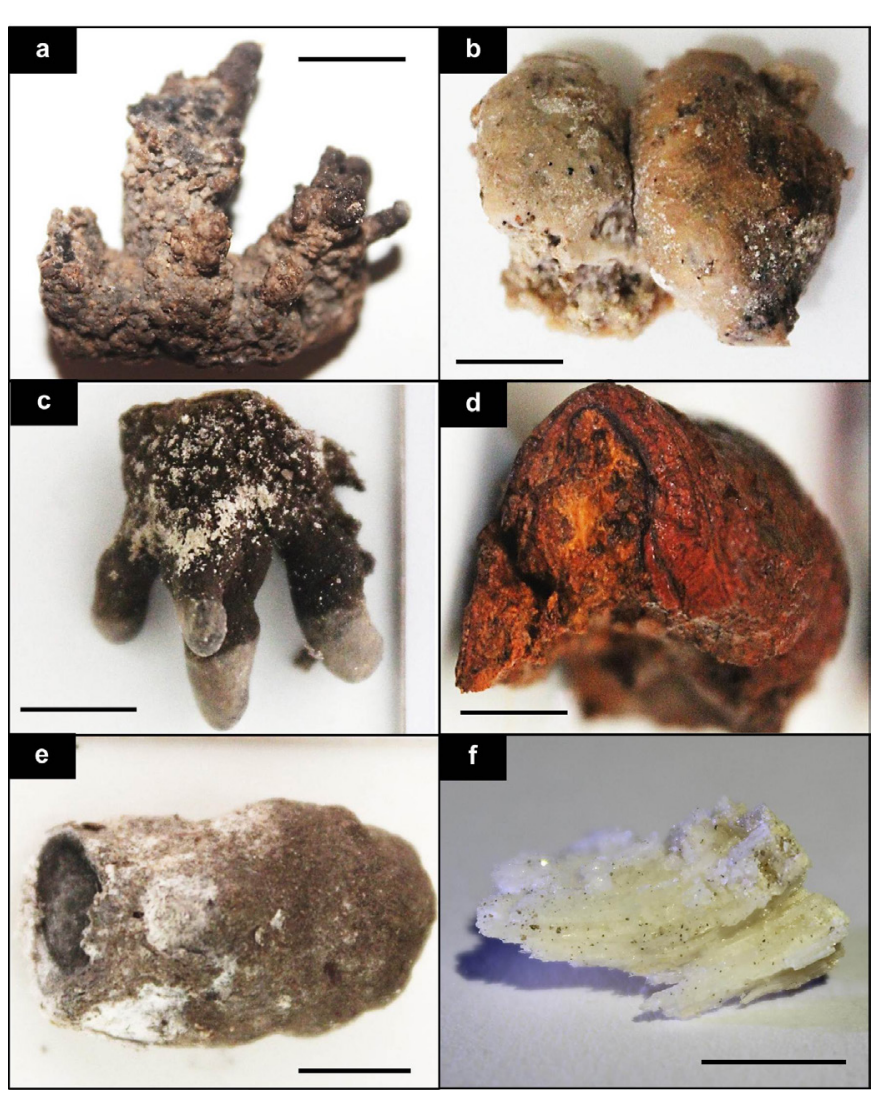

Fig. 2. Speleothems of caves in the study area: a) arborescent (coral), Caverna da Chaminé; b) mushroom-shaped, Buraco do Padre; c) stalactitic, Caverna da Chaminé; d) stalagmitic, Caverna do Zé; e) columnar with horizontal/ascending growth, Sumidouro do Córrego das Fendas; f) fibrous, Fenda Sem Fim. Graphic scale: 1 centimeter. 

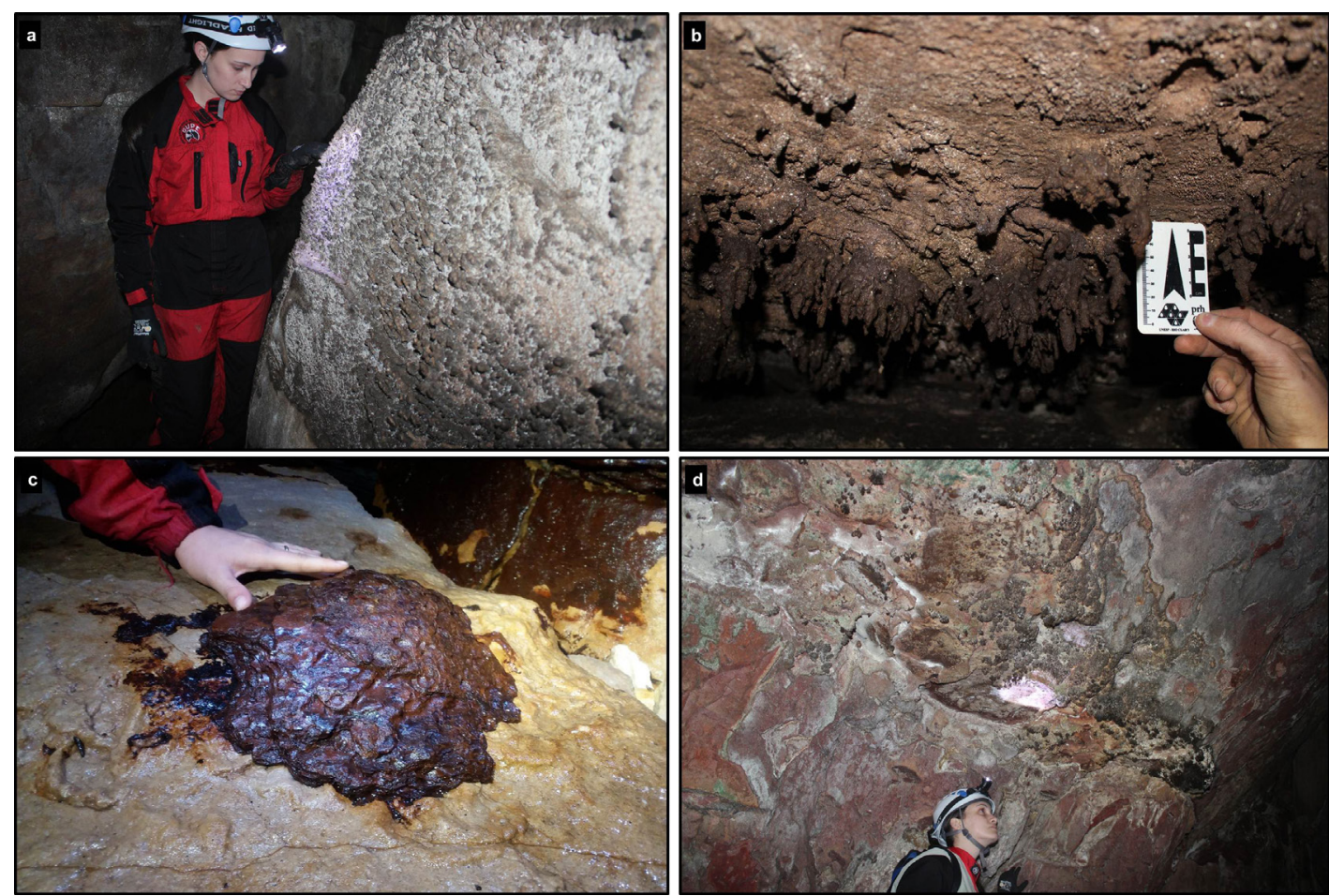

Fig. 3. Speleothems in their original location (in cave). a) Columnar speleothem with horizontal/ascending growth on the wall of the Caverna das Andorinhas; b) Arborescent speleothems in Sumidouro do Córrego das Fendas; c) Stalagmite speleothem in Caverna das Andorinhas; d) Arborescent speleothems in Gruta Andorinhas da Pedra Suspensa.

Arborescent speleothems are the most commonly found in the study area. They occur as main structures that branch into dendritic segments, usually with irregular or rugged surfaces. The mushroom-shaped speleothems resemble pileus (hats) of some varieties of fungi, usually in convex shapes. They occur alone or in groups, also with rugged or smooth surfaces.

Stalactitic speleothems usually project downward from cave ceilings as columnar forms with rugged or smooth surfaces. Stalagmitic ones rise from the floor in rough or smooth convex forms whose origin is usually associated with dripping water, occurring predominantly in red, but also in orange and black shades in some portions. Columnar speleothems of horizontal/ascending growth form on cave walls and floors, usually in rugged columnar shapes. The fibrous one consists of filamentous crystal clusters with irregular surfaces, in yellowish-white colors. Except for the stalagmitic and filamentous ones, the speleothems can assume various shades of white, gray and brown. However, their color relates to the presence of coloring mineral components such as iron oxide, and not to morphological characteristics.

\section{Composition}

Similarly as in speleothems of the Vila Velha sandstones (Fig. 4b), silicon and aluminum form the arborescent, mushroom-shaped, stalactitic and columnar with horizontal/ascending grow speleothems found in Furnas Formation quartz-sandstones (Fig. 4a). In the present study, X-ray diffraction indicates the presence of opal-A, cryptocrystalline silica and cryptocrystalline kaolinite (Fig. 4c-f) as mineral components. The presence of Opal-A was diagnosed by comparison with siliceous speleothems of other regions of the globe (e.g., Finlayson \& Webb, 1985; Wray, 1999;
Aubrecht et al., 2008). The quartz peaks present in the graphs, in addition to being the result of the presence of detritic quartz, represent cryptocrystalline silica, possibly chalcedony.

Muscovite is also present, in detritic fragments weathered and transported from silt and clay layers by water and imprisoned in biofilms.

The stalagmitic speleothems identified in the caves known as Caverna do Zé and Caverna das Andorinhas (Furnas Formation) are composed entirely of iron oxides, specifically amorphous varieties associated with goethite and hematite (Fig. 5a, b). Fibrous speleothems occur only as a small set of features, in a cave known as Fenda Sem Fim, developed in rocks of the Furnas Formation (Fig. 5c). An unprecedented fact is the presence of speleothems formed solely by gypsum in rocks of the Furnas Formation. Being this a unique and small occurrence, only material for determination of chemical composition by X-ray diffraction could be collected (Fig. 5d).

\section{Biological records}

SEM images revealed the presence of several biosignature elements including molds, fragments and even complete structures of past microorganisms in speleothems developed on Furnas Formation and Vila Velha Sub-unit rocks. Such biological markers are present in massive portions of speleothems, composed of silica, being also considered the most important records of microbial action in the study area (Fig. 6a, b). In some speleothems, clusters possibly formed by cyanobacteria appear as filamentous biofilms segmented by globules (Fig. 6c, d).

Several speleothem samples present fully preserved microorganisms, possibly corresponding to fossil structures (Fig. 6e). Also, other biological organisms 

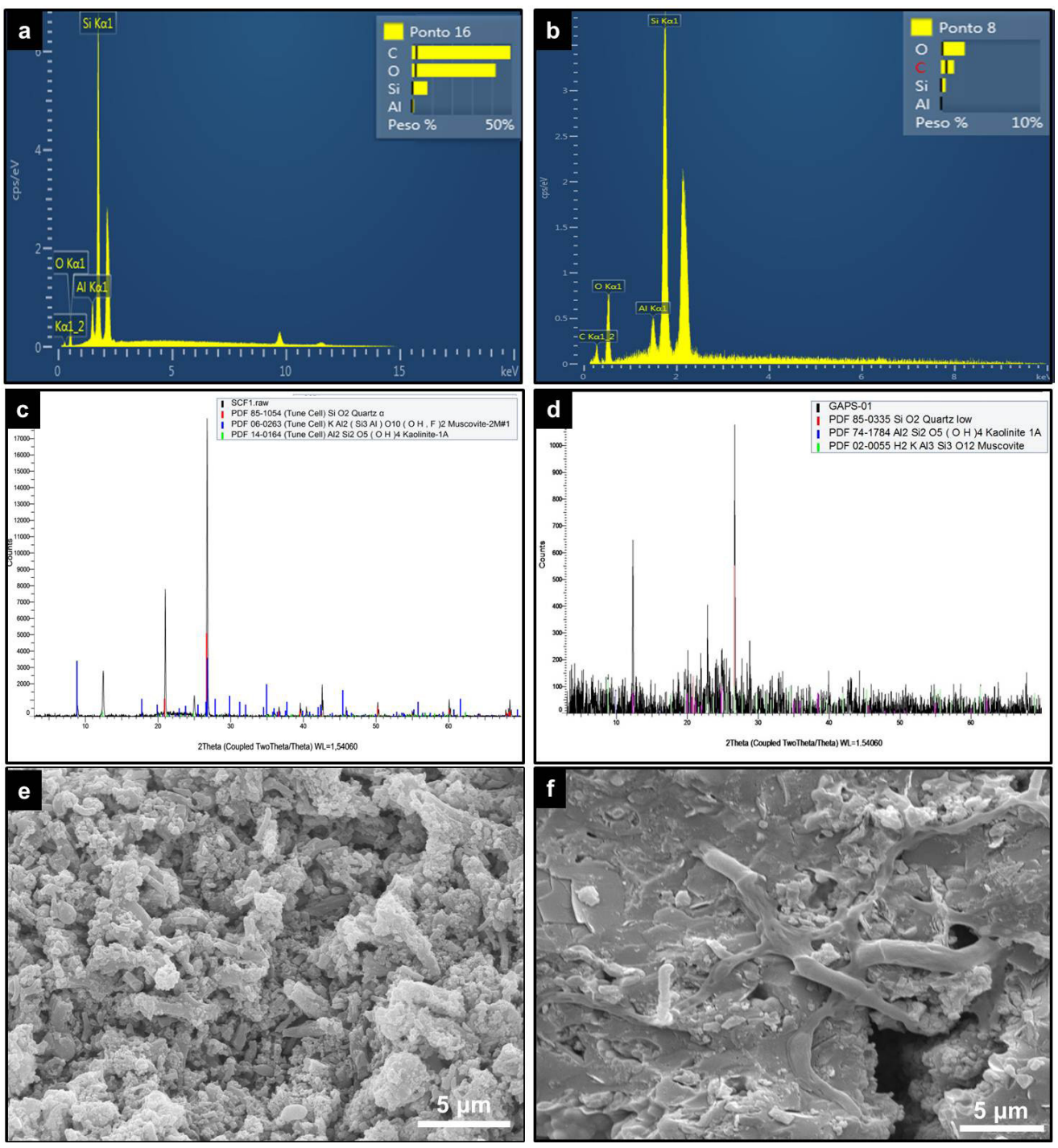

Fig. 4. Energy-dispersive spectrometry analysis of cave speleothems. Silicon and aluminum: a) Gruta da Inspirada, Furnas Formation; b) Gruta Andorinhas da Pedra Suspensa, Vila Velha Sandstone; c) X-ray diffraction analysis indicating opal-A (Finlayson \& Webb, 1985) and kaolinite as mineral components of speleothems of the Sumidouro do Córrego das Fendas, Furnas Formation; d) Gruta Andorinhas da Pedra Suspensa, Vila Velha Sandstone; e-f) Speleothemes composed of cryptocrystalline silica.
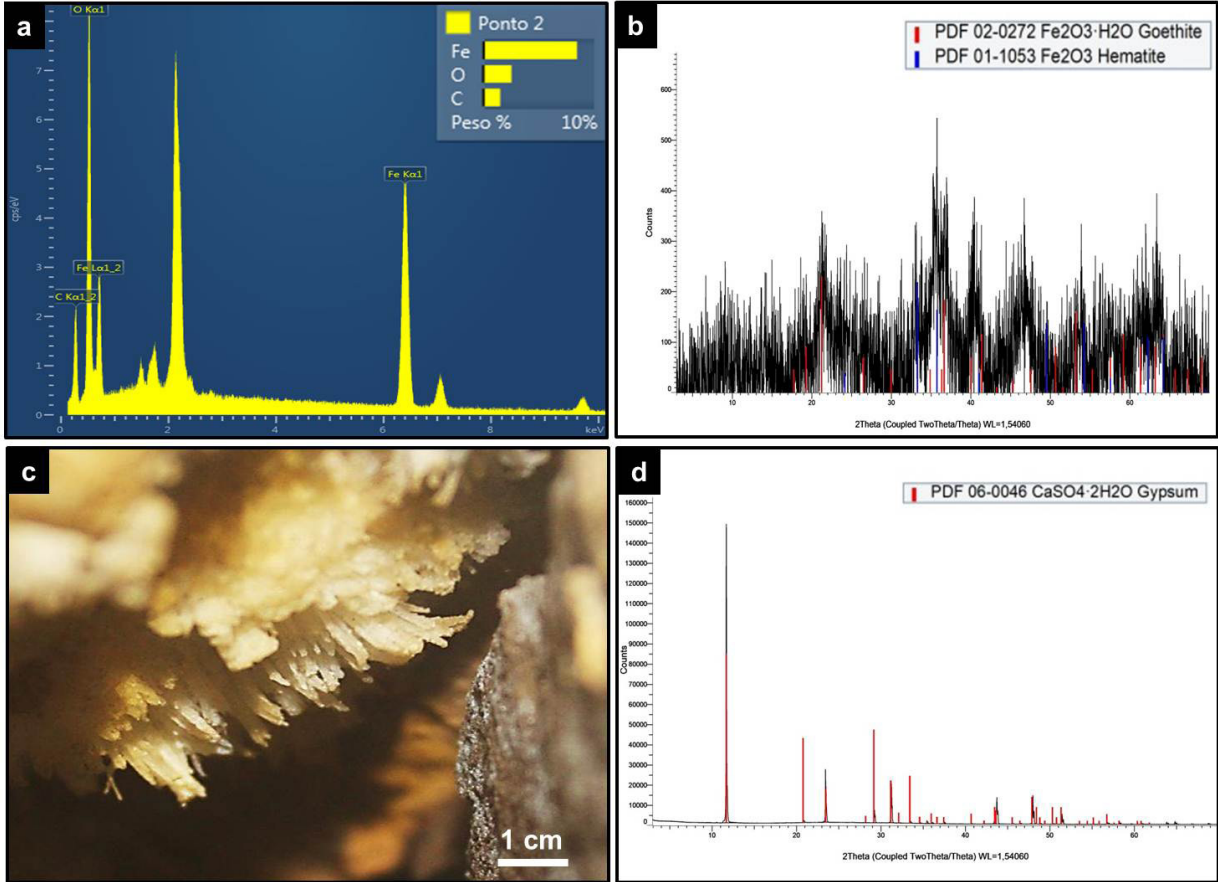

Fig. 5. a) Energy-dispersive Spectrometry analyses indicating iron oxide in the composition of stalagmitic speleothems found at Caverna do Zé, a cave in Furnas Formation rocks; b) X-ray diffraction defining the composition of the same secondary mineral deposit, iron amorphous oxide associated with hematite and goethite; c) small set of fibrous speleothems in the Fenda Sem Fim cave system, Furnas Formation; d) X-ray diffraction results indicating gypsum in the composition of said deposit. 
were trapped during chemical precipitation, especially in the initial stages of formation. Remnants of biological materials such as plant fragments, invertebrates (whole shells and molds), diatoms, amoeba and many types of fungal and plant spores were also identified (Fig. 6f-i; Fig. 7a-h).

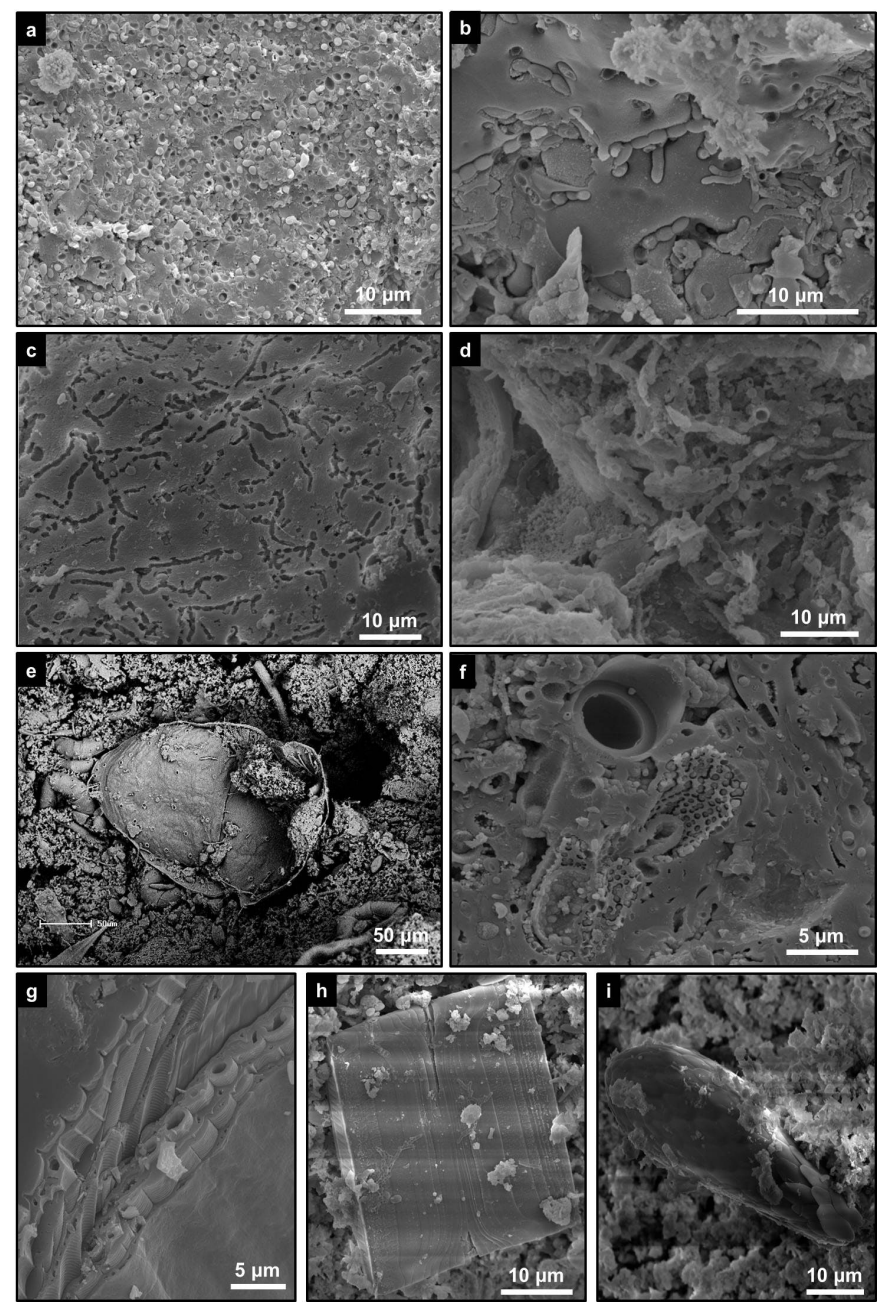

Fig. 6. Secondary SEM images showing biological components in Furnas and Vila Velha Sandstone speleothems: a) bacteria cocci (or archea); b) different bacteria grouped as globular filaments surrounded by secondary precipitation of silica, and possibly Bacillus sp. on the right of the image; c) biosignatures in secondary precipitation of silica; d) various microscopic organisms forming a biofilm; e) completely silicified mite; f) frustule of possible diatom Aulacoseira sp.; g) plant fragment similar to a microleaf; h) unidentified diatom; i) Testate Amoebae possibly Euglypha sp.

\section{Internal structures}

Total porosity values obtained by visual quantification under petrographic microscopy vary according to the type of speleothem, even at hand sample scale when distinct internal sectors of the feature are considered. Mushroom-shaped speleothems are the most porous ones compared to other varieties. Conversely, speleothems bearing well-defined internal microlaminations, as do arborescent, stalactitic and columnar ones tend to present low total porosity values.

Under micro-CT analysis, a columnar speleothem with horizontal growth from Sumidouro do Córrego das Fendas cave (Furnas Formation) showed a total porosity of approximately $7 \%$, while an arborescent deposit in the cave known as Gruta Andorinhas da Pedra Suspensa (Vila Velha Sandstone) presented a value of $3.7 \%$ for the same property (Fig. 8). However,
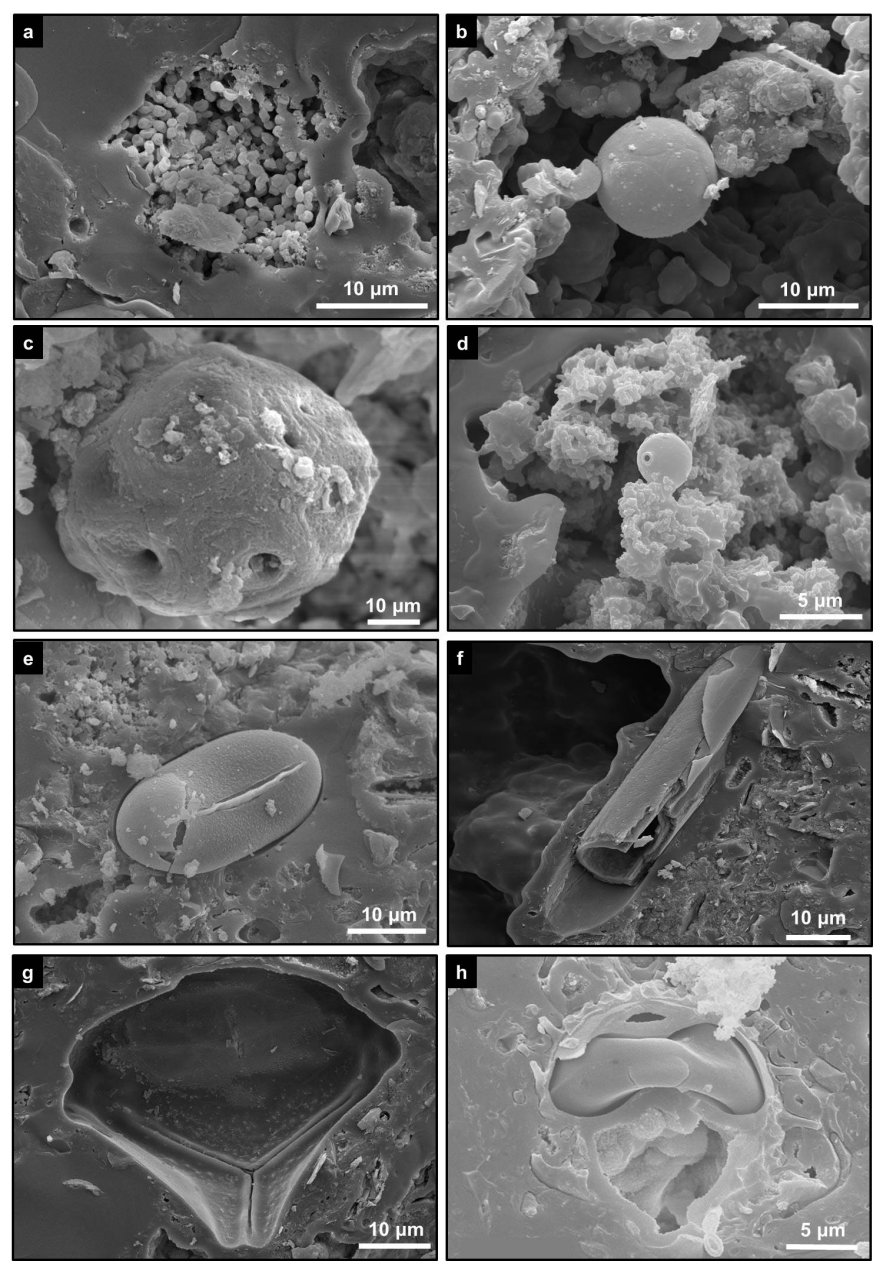

Fig. 7. Furnas Formation and Vila Velha Sandstone speleothems showing fully siliceous biological materials: a) microorganisms occupying a pore; b-e) unidentified biological structures; f) plant fragment; g) microorganism mold; h) partially preserved structure of unidentified microorganism.

total porosity tends to be higher in the outermost portions of speleothems, reaching $27.4 \%$ in a Furnas Formation specimen, and $7 \%$ in another one developed on Vila Velha sub-unit. The same aspect was revealed by Transmitted Light Microscopy (Fig. 9a, b).

Three, inner, intermediate and outer microfacies could be identified in arborescent, stalactitic and columnar with horizontal/ascending growth speleothems by applying Transmitted Light Optical Microscopy to thin sections perpendicular to older, inner microlaminations, and thin sections perpendicular to younger, outer microlaminations of speleothems (Fig. 10a).

In the inner microfacies, well-defined overlapping microlaminations indicate the growth direction of the speleothem (Fig. 10b). Colors vary between brown and white, the laminae being evenly spaced from one another. Quartz grains, and muscovite lying concordantly to lamination are the main constituents. As the deposit took shape, mineral grains adhered to surface irregularities and biofilms.

Lamination in the intermediate microfacies is incipient, ranging from dark brown to white. Laminae are thicker compared to those of the inner microfacies (Fig. 10c). Pores and biological components, mostly represented by plant fragments, are more frequent.

Microlaminations are not found in the outer microfacies, that presents itself with a disorganized 


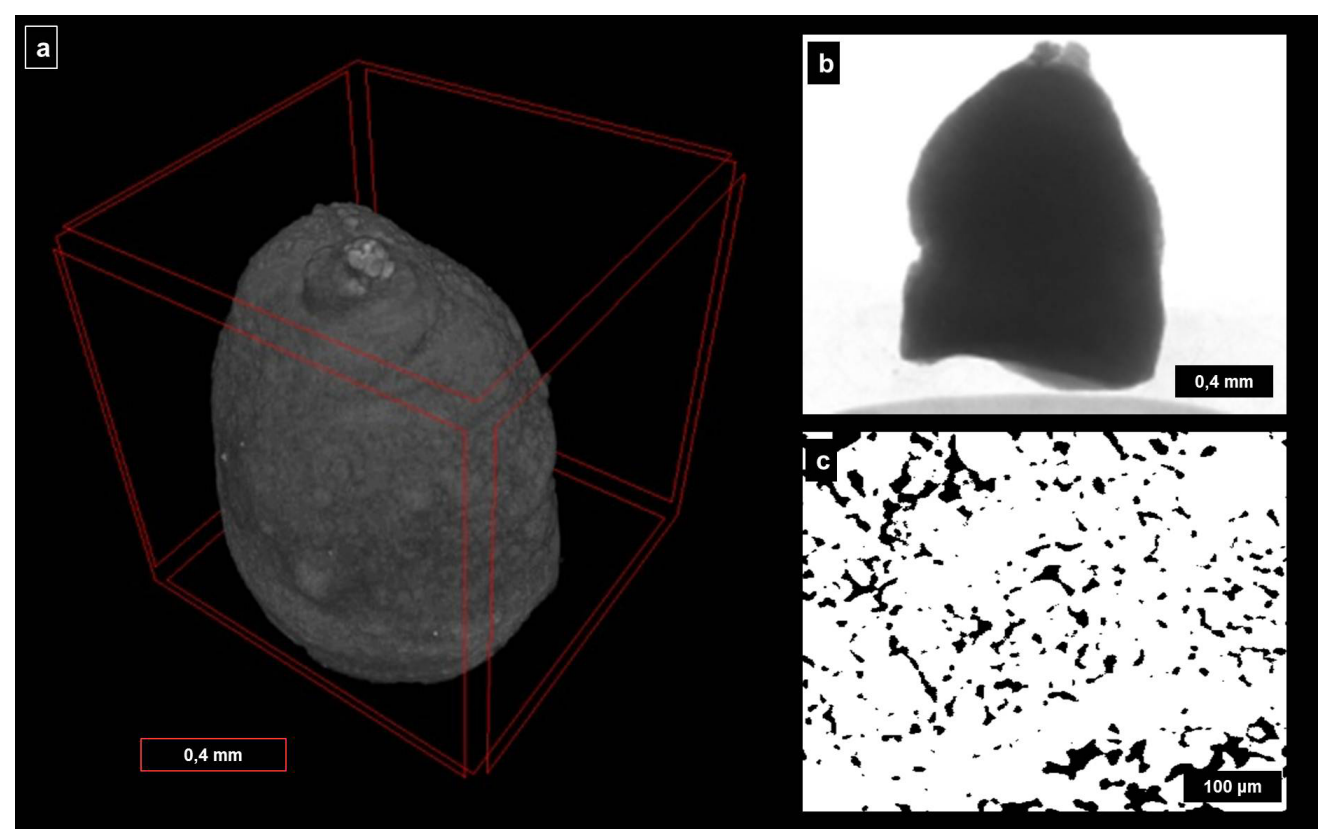

Fig. 8. Micro-CT analysis in columnar speleothem with horizontal/ascending growth. 3D image (a) and 2D image (b) of the analyzed speleothem; c) One of the hundreds of binary images generated by computerized microtomography used for the semi-automatic interpretation of the total porosity of the speleothem.
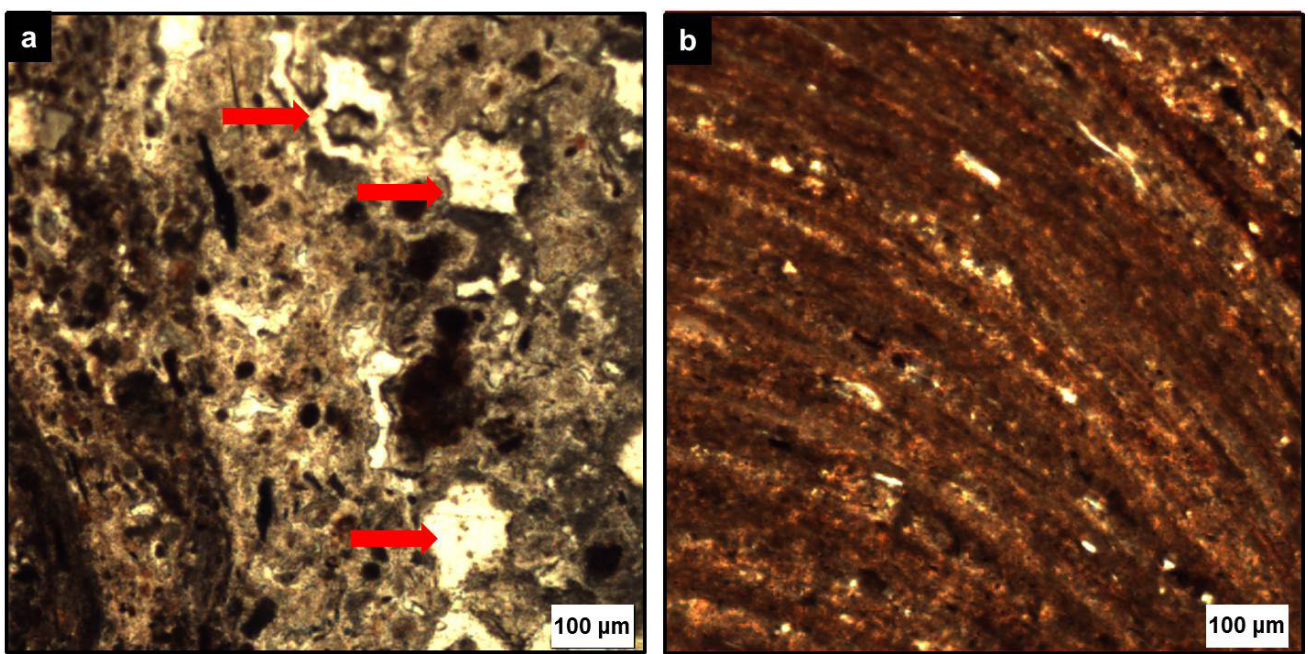

Fig. 9. Thin section photomicrographs with parallel polarizers showing: a) high porosity in the outer portion of a speleothem (red arrows indicating pores) and b) a low porosity in inner microfacies.

aspect. Dark brown shades predominate, with sparse light portions (Fig. 10d). Porosity and the amount of biological components, especially plant fragments, are higher compared to the other microfacies (Fig. 10e-h). In some cases, light portions of the outer microfacies present wavy or fringed laminae similar to those described in stromatolites of carbonate sedimentary rocks by Iespa et al. (2012).

Petrographic analysis of thin sections of a small portion measuring $1.07 \mathrm{~cm}$ in length of an arborescent speleothem revealed the presence of 78 laminae, 39 dark and 39 light ones (Fig. 10i). Lamination thickness ranges from $20 \mu \mathrm{m}$ to $1.93 \mathrm{~mm}$. The thinnest laminae are found in the inner microfacies, while the thicker ones are concentrated in the outer microfacies. The alternation of colors between laminated pairs is given by differences in speleothem accretion phases, possibly related to periods of higher or lower humidity.

Stalagmitic speleothems present two distinct interspersed microfacies (Fig. 11a, b), one with a tenuous microlamination from red to yellow shades
(Fig. 11c), and another one, predominant in this type of speleothem, composed of well-defined red to black laminae below reddish to orange columnar microstructures (Fig. 11d). These columnar microstructures correspond to portions of high bacteria concentration, possibly Gallionella ferruginea, as revealed in SEM images.

Mushroom-shaped forms do not have a defined internal structure pattern, possibly because they correspond to initial stages of spelothem development, are in full genetic activity. Due to low physical resistance, thin sections of these materials could not be mounted. However, in scanning images they show to be disorganized deposits devoid of microlaminations (Fig. 11e).

\section{Patterns of occurrence}

Geological sections and faciological characterization of the rocks that form the substrate to speleothems show that these features develop in all sandstone lithofacies regardless of granulation, sorting or degree of cementation. Less often, and to a lesser extent, these 

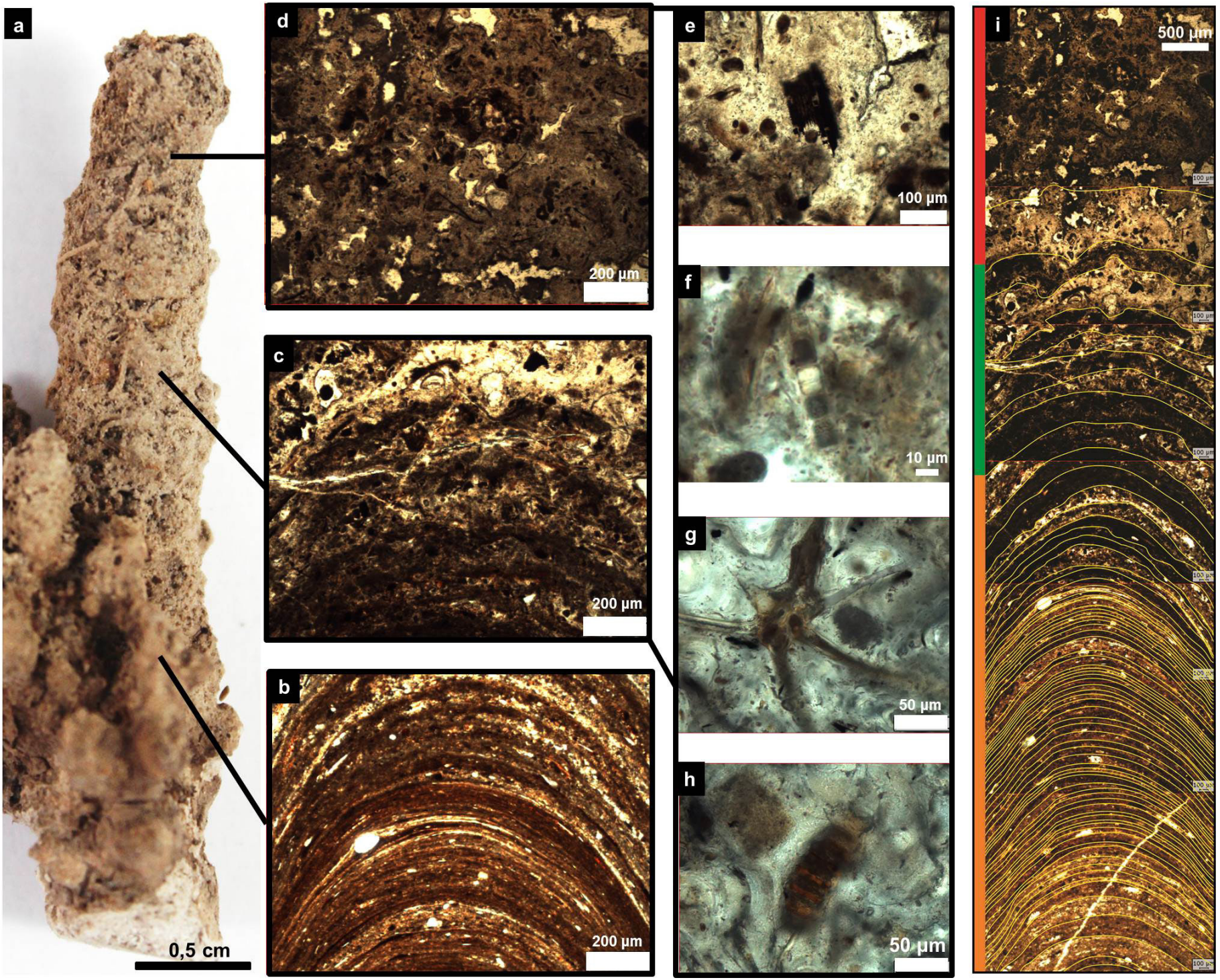

Fig. 10. a) Arborescent speleothem and thin section photomicrography under parallel polarizers showing the subdivisions of the speleothem, b) inner microfacies, c) intermediate microfacies, and d) outer microfacies. e) In intermediate and outer portions are several biological elements such as plant fragments (dark central part) and spores of fungi and pollens (black and brown spheres); f) Melosira sp. diatom; g) Amoeba radiosa; h) unidentified microorganism. i) Photomicrographs of an arborescent (coral) speleothem showing 78 microlaminations (delimited by yellow lines). The lateral colors represent microfacies boundaries: inner, orange; intermediate, green; outer, red.

deposits occur in silty-clayey layers and conglomerate strata of the Furnas Formation.

Bedding, stratification and fracturing planes exert evident control over the development of speleothems. In some cases, weathering features are associated with neoformed mineral deposits. This does not constitute a rule, however, since speleothems are present in both friable and diagenetically silicified portions of the sandstones.

As already mentioned, speleothems develop in underground and surface cavities, from aphotic to dim to fully illuminated environments (Table 1). Conversely, humidity and temperature exert direct influence on the formation of these features. Also, it is important to highlight the fundamental role played by aerosols in the formation of speleothems in underground cavities, as already pointed out by Klimchouck et al. (1997), Maltsev (1997), and Dredge et al. (2013).

\section{Deposits like rimstones}

Features known as rimstone are found in outcropping areas of Furnas Formation and Vila
Velha sandstones. Some descriptions of the study area report such features as speleothems (e.g., Massuqueto, 2010; Pontes, 2010; Flügel Filho et al., 2012). However, petrographic analysis and SEM reveal that their characteristics are not of secondary chemical, but clastic deposits.

Deposits like rimstones are formed by displacement of soils and organic matter from the surface of the terrain into caves by water that infiltrate sedimentary and tectonic discontinuities. Water and sediments flow through the walls of caves forming cascadelike accumulations and rigid crusts after circulation ceases.

The clastic deposits thus formed vary in grain size, but with a predominance of silt and clay. The relative plasticity determined of silty and clayey fractions allows deposits to manifest in typical shapes due to the constant flow of water and sediments over previously existing layers, in a process described by Vidal Romaní et al. (2014) in granite caves.

These features developed on vertical walls, where water flow is more intense, exhibit rugged surfaces and varied concave, convex, fringed shapes forming 


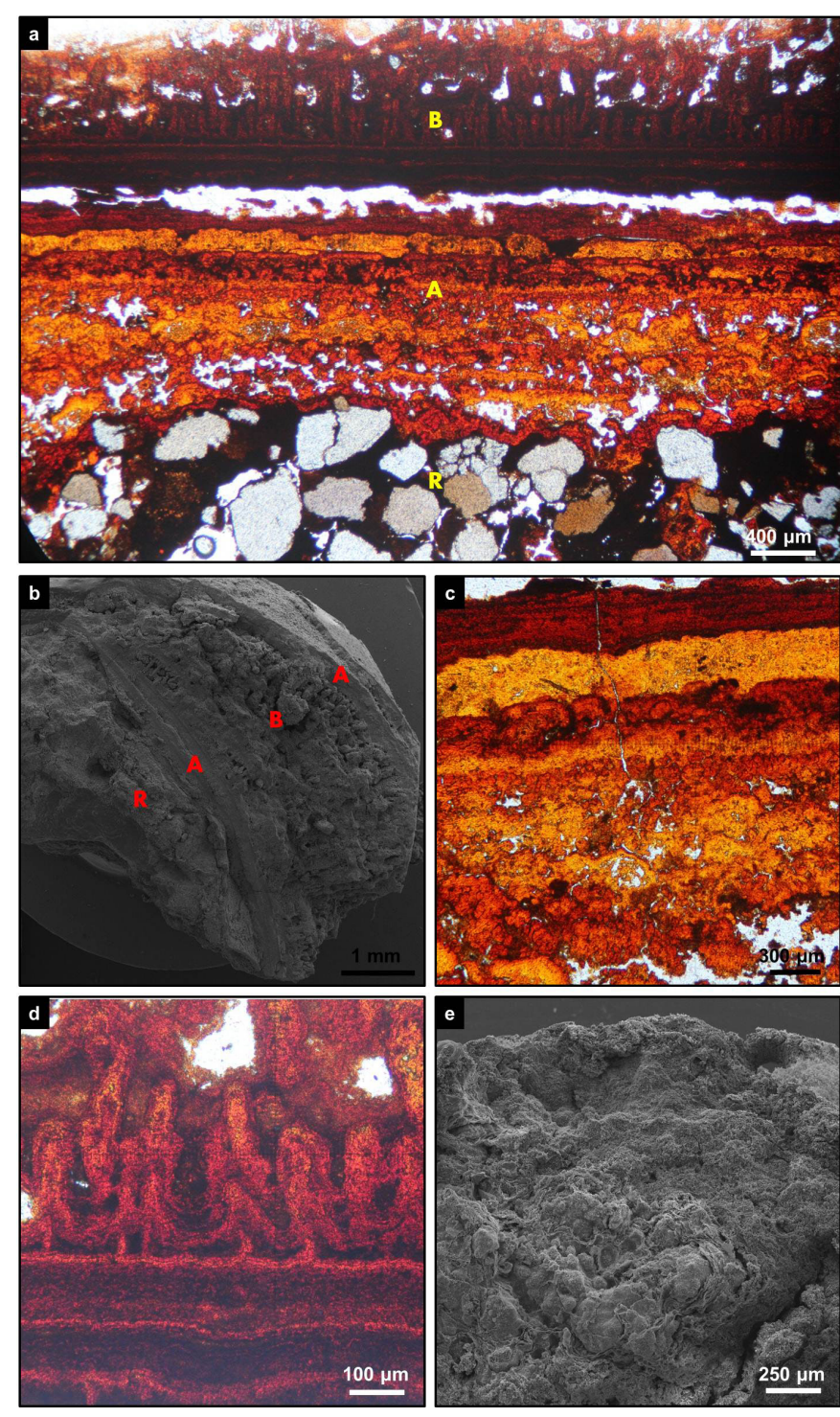

Fig. 11. Stalagmitic speleothem microfacies: a) with tenuous microlamination ranging from red to yellow $(A)$; well-defined red to black microlamination superimposed by a red to orange columnar microstructures with highly concentrated bacteria (possibly Gallionella ferruginea) (B); rock or sediment over which the speleothem developed (R); b) Secondary electron image showing alternation of two microfacies in stalagmitic speleothem; Thin section photographic of microfacies A (c) and B (d); e) Secondary electron image of mushroom-shaped speleothem lacking internal structure, without microlamination.

microterraces. Over ramps, where water flow is less intense, small dams and pools (micro-gours) commonly form due to the slow and irregular displacement of water on the sediments.

Even though the studied specimens do not show speleothem characteristics, the possibility of mineral precipitation in such deposits is not excluded, their outer portions being worth of detail studies, especially where rigid crusts are present. Also, such features are highly capable of capturing components of biological origin, thus potentially serving as paleoenvironmental and paleoecological markers.

\section{DISCUSSION}

\section{Genetic aspects}

Melo et al. (2015) point out that in rocks of the Furnas Formation the arborescent, mushroomshaped, stalactitic and columnar with horizontal/ ascending grow speleothems varieties are composed of amorphous to cryptocrystalline silica and cryptocrystalline kaolinite. Several studies point to continuous evaporation cycles as triggers of silica precipitation, indicating that speleothems only develop in areas with free circulation of air under unsaturated atmosphere (e.g., Webb \& Finlayson, 1984; Hill \& Forti, 1997; Wray, 1999). However, clusters of globular microbial filaments (possibly cyanobacteria) were found in samples, forming extracellular polymeric biofilms (Fig. 12a). Such biosignatures show features that result from microbiological action, which allows such secondary chemical deposits to be classified as microbialites or biospeleothems. The genesis of speleothems is, therefore, induced or influenced by microorganisms.

Several studies discuss the influence of microbial metabolic activity on the precipitation of silica (e.g., Cañaveras et al., 2001; Forti, 2001; Aubrecht et al., 2008; Loves \& Warren, 2009; Daza Brunet \& Bustillo Revuelta, 2014; Lundberg et al., 2018). Similarly, some microorganisms are also capable of modifying chemical conditions of rocks at the microenvironment scale (millimeter by centimeter), thus possibilitating local dissolution of silica (Bennet, 1991; Ehrlich, 1996; Brehm et al., 2005; Vidal Romaní \& Rodriguez, 2007; Miot et al., 2014).

According to Baskar et al. (2007); Sallstedt et al. (2014); Zepeda Mendoza et al. (2016), biofilms play an important role in the genesis of some speleothems. The presence of biofilms associated with cave speleothems in the study area such as in Furna do Buraco do Padre (Furnas Formation) and Gruta Cambiju I (Vila Velha Sandstone) implies biological action in the development of these geological features (Fig. 12b). Thus, SEM proved to be an efficient method to detect biosignatures, as pointed out by to Miot et al. (2014).

Not only are polymeric extracellular substances able to adhere to particles that touch the biofilm such as mineral grains and biological organisms or fragments, but they can also promote precipitation of secondary minerals such as silica, kaolinite and iron oxides. Figure 13 outlines the formation of arborescent, stalactitic, columnar with horizontal/ ascending growth, mushroom-shaped and stalagmitic spelothems, showing that the process starts with water percolating the rock and the removal of ions and molecules from the surface of mineral components by various chemical processes. Subsequently, the solution reaches the biofilm, where microbial metabolic processes promote the precipitation of chemical elements to form speleothems. Overlapping microlaminae are accreted to the speleothem as the cycle repeats, a process not observed only in mushroom-shaped speleothems, which correspond to deposits in early development stages.

In addition to microbial action, the development of some speleothems may be influenced by the presence of spider webs, especially in arborescent types. Field observation allowed to identify the action of different spiders species on speleothems. Aubrecht et al. (2008) and Lundberg et al. (2010) report mineral precipitation 

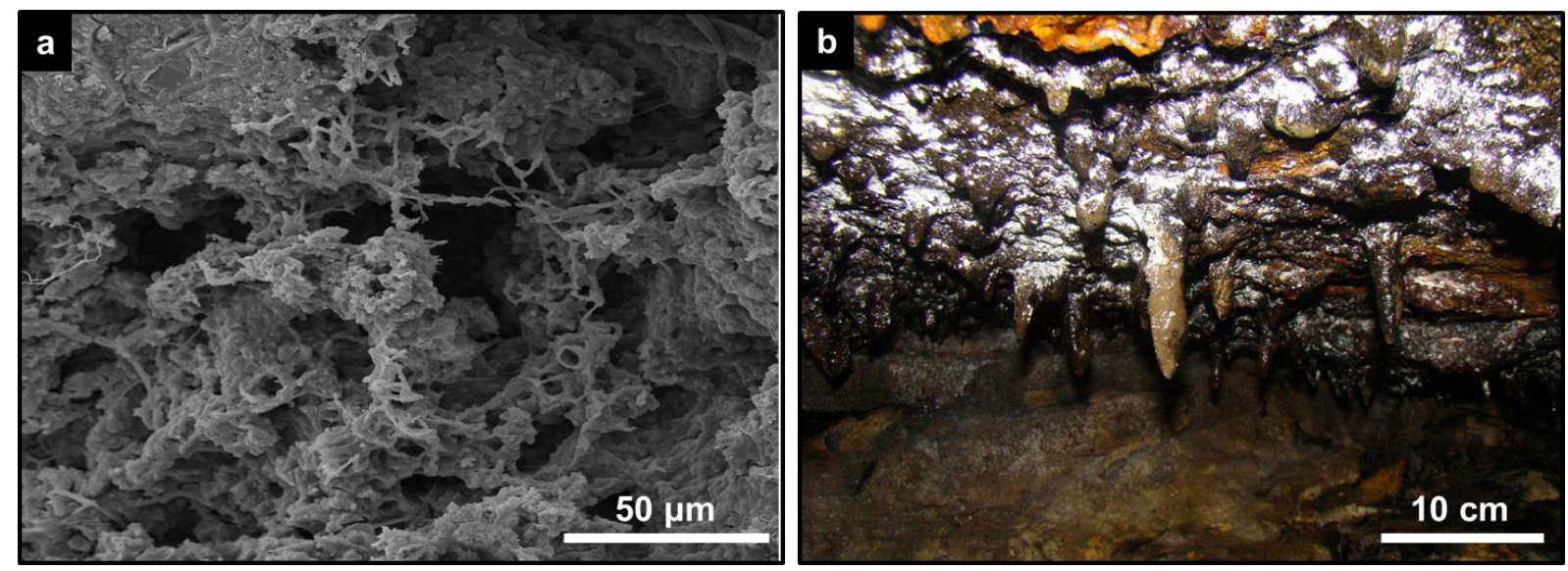

Fig. 12. a) SEM images of the Gruta da Inspirada speleothem (entrance area, with light) showing biofilm-forming microorganisms; b) Speleothem biofilms at Gruta Cambiju I, Vila Velha Sandstone, in entrance area (with light).

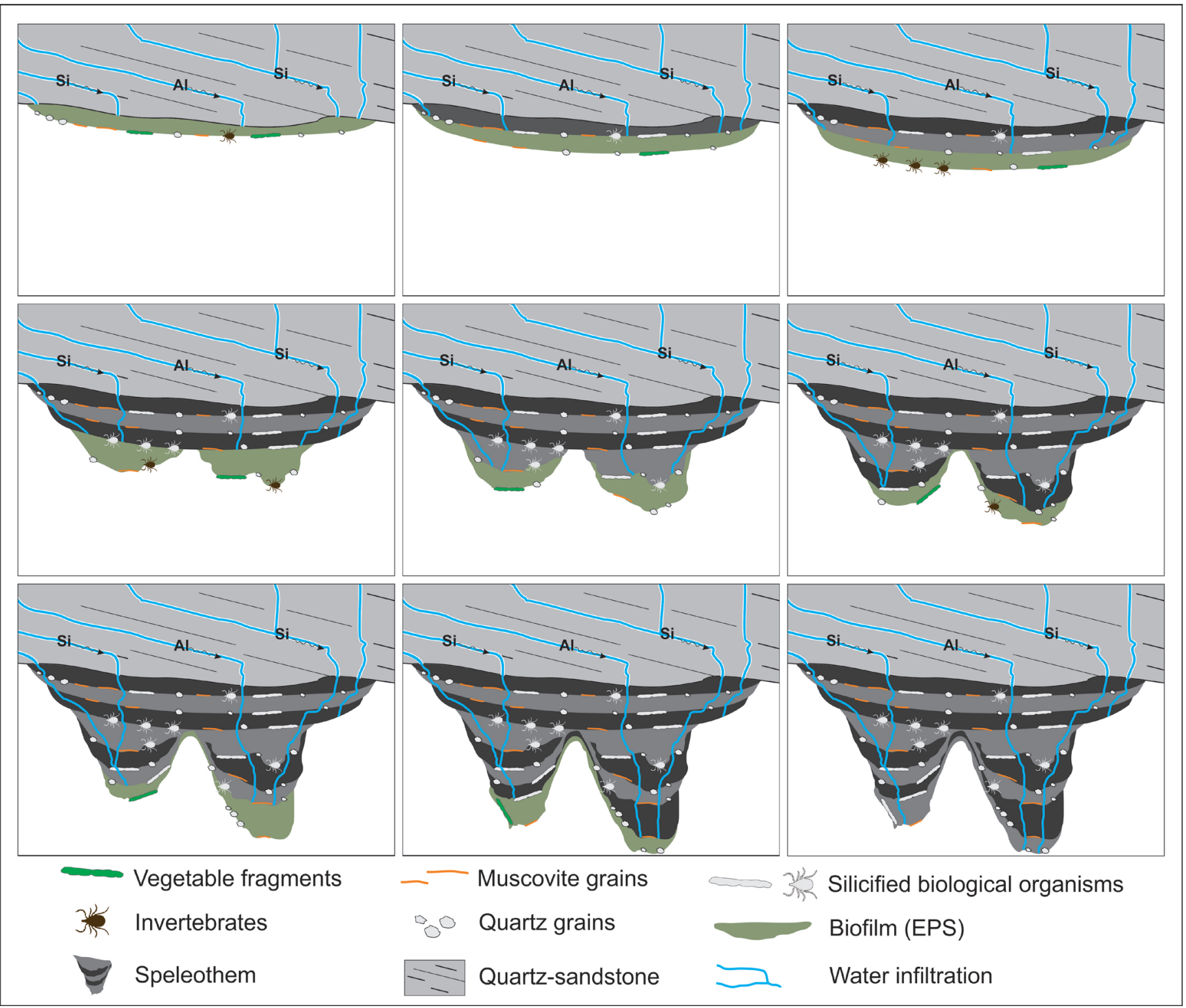

Fig. 13. Speleothems in the study area (except for fibrous type); biofilm mediation (exopolysaccharides).

along web strands, forming what those authors refer to as cobweb stalactites. Silica precipitation along spider web strands was identified in Furnas and Vila Velha sandstone speleothems, evidencing that these filaments can serve as preferential sites for the mineral incrustation (Fig. 14a, b). Elongated structures up to 5-10 $\mu \mathrm{m}$ in diameter interpreted as originally corresponding to web strands were identified on thin petrographic sections. According to Pontes et al. (2018a), at least five families of these invertebrates distributed over five different morphospecies produce webs in speleothems of the study area.

Stalagmitic speleothems result from dissolution of ferruginous incrustations along fractures and faults. Water rich in solubilized iron infiltrates the cave ceiling, accumulating such components over 
the ground usually by dripping. These speleothems can be classified as microbialites given the presence of numerous clusters of bacteria, possibly Gallionella ferruginea (Fig. 14c, d). These microorganisms produce polymeric extracellular substances in the form of twisted ribbon-like stems on which iron oxide precipitates, as reported by Søgaard et al. (2001), Hallberg \& Ferris (2004), Zhilei et al. (2010), and Chan et al. (2011).

Owing to their rarity, fibrous speleothems constitute secondary mineral deposits of high scientific value in the region of Campos Gerais do Paraná. Based on comparisons of color and habit, Pontes et al. (2017) report similar speleothems only in the cavity known as Abrigo Casa de Pedra da Granja, formed in rocks of the Itararé Group in Tibagi municipality, $90 \mathrm{~km}$ from the study area.

In a gypsum speleothem found in the cave known as Fenda Sem Fim (Furnas Formation), the source of sulfate may correspond to the guano of bats and biscutate swifts (Streptoprocne biscutata), the latter a typical species in the region. Oxidation caused by fungi and bacteria is able to promote precipitation of sulfate from decomposing organic matter, as pointed out by Vidal Romaní et al. (2010) and Aubrecht et al. (2012). The chemical alteration of feldspars present in Furnas Formation sandstones (Borghi, 1993) may represent the source of calcium. Sauro et al. (2014) point to the possibility that microbially reduced atmospheric sulfate from forests or peatlands be carried as aerosols to the interior of caves by air streams. However, the reduced occurrence in one single cave leaves the origin of such secondary mineral deposits open for discussion. Specific microclimatic conditions of temperature, humidity and luminosity combined with the availability of chemical elements (Ca and S) are deemed fundamental factors to the formation of this variety of speleothems.

The speleothems alternating laminae are of potential use as annual or seasonal climatic markers, as pointed out by Sallstedt et al. (2014), Riechelmann et al. (2016), and Zepeda Mendoza et al. (2016). Regarding differences in porosity (low porosity in the innermost portions), they possibly result from the time interval elapsed during speleothem accretion. Older, internal sectors tend to be less porous and better microlaminated than external ones. Decomposition of organic matter, mineral substitution and compaction are factors related to low porosity. In some cases, porosity also results from microbial action, involving mineral precipitation inside speleothems due to current biological colonization by diatoms, bacterias and other microorganisms able to promote precipitation of silica. The alternation of colors among laminae may also be related to differences in mineralogical composition. In siliceous speleothems of Australian caves, Wray (1999) noticed an alternation of light laminae composed of chalcedony and dark laminae composed of chalcedony and opal-A/chalcedony.

Studying speleothems developed on quartzite, sandstone and granite, which are silica-rich types of rocks, Fernandéz Verdía et al. (2000) noticed silica precipitation by microbial action in pores of these deposits forming portions with no empty spaces. The same authors attribute rhythmic accretion structures in concentric layers to biogenic processes. Similar features were identified in several samples in cavities of both Furnas and Vila Velha rocks which are therefore considered evidence of biologically induced mineralization (Fig. 15).
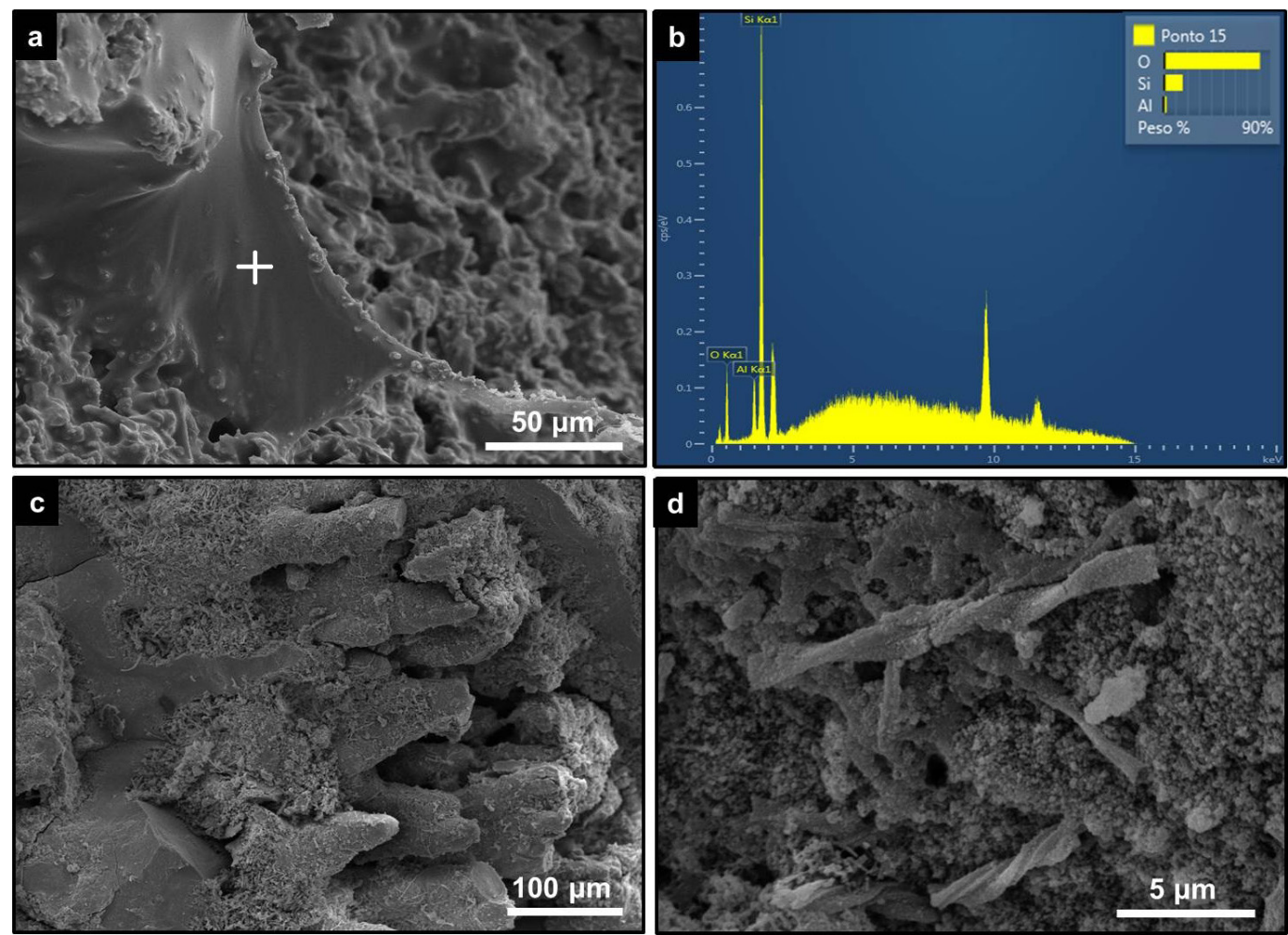

Fig. 14. Secondary electron image showing silica precipitation around a spider web; a) White cross indicates EDS target; b) EDS analysis indicating silica precipitation around spider web threads; c) SEM images of exopolysaccharide-forming bacteria (possibly Gallionella ferruginea) partially surrounding a dendritic stalagmite; d) Polymeric extracellular substances excreted by bacteria to form a twisted band. 

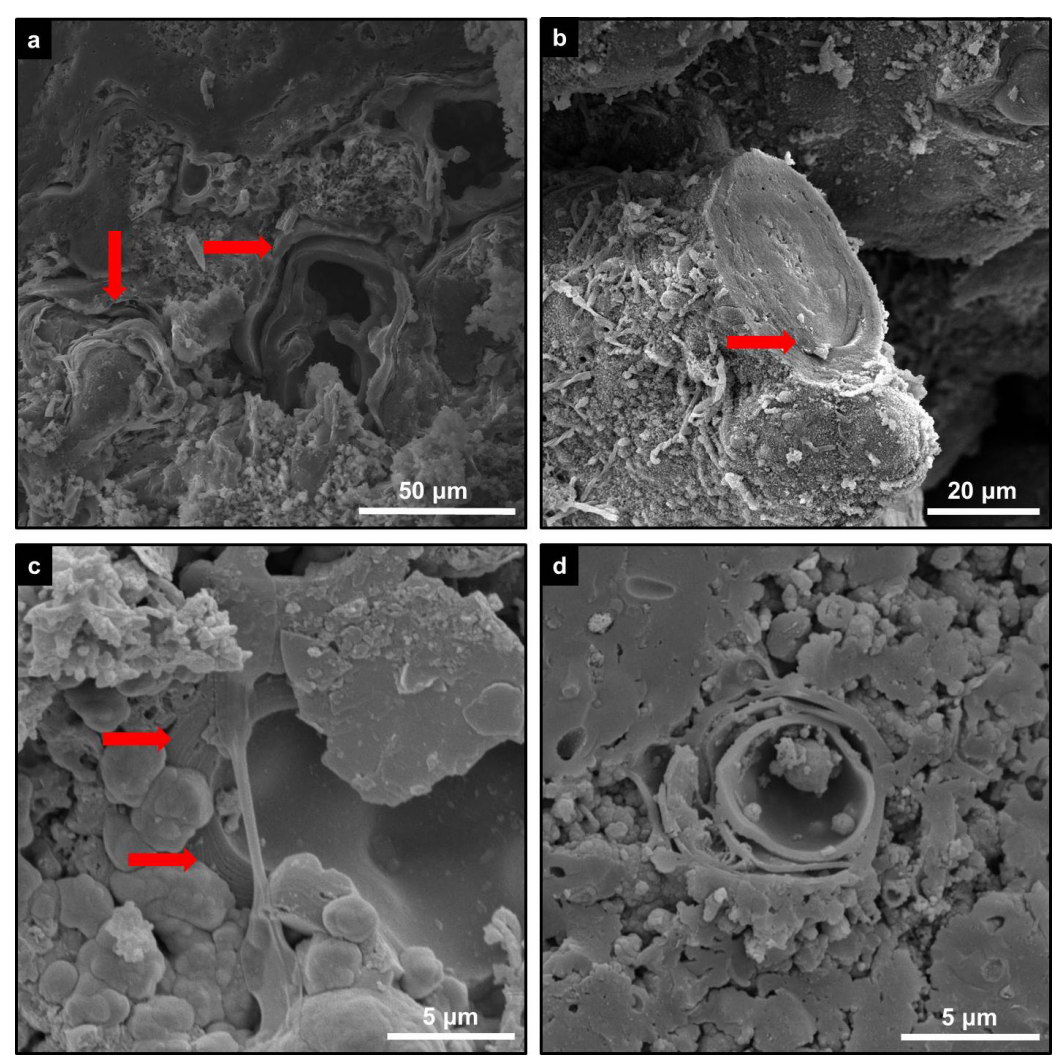

Fig. 15. Secondary electron images showing layers of rhythmic concentric accretion (red arrows) evidencing organomineralization.

\section{CONCLUSION}

The speleothems formed on Furnas Formation and Vila Velha sub-unit quartz-sandstones present themselves in six types: (1) arborescent, (2) mushroomshaped, (3) stalactitic, (4) stalagmitic, 5) columnar with horizontal/ascending growth, and (6) fibrous. The deposits like rimstones of the study area are more properly classified as clastic deposits since they bear no evidence of chemical precipitation, despite being considered speleothems in previous studies. Nonetheless, the possibility of mineral precipitation is not ruled out. Detail studies on outer portions of some deposits are therefore necessary, especially where rigid crusts are present.

Biosignatures, various bacteria forms (possibly cyanobacteria and Gallionella ferruginea), diatoms and other microorganisms capable of promoting precipitation of minerals such as silica, kaolinite and iron oxides were identified in several of the speleothems studied. Microbial action records are present in nearly all samples studied, suggesting biological influence on the genesis of speleothems. These secondary mineral deposits can herefore be classified as microbialites as their genesis involved biologically induced mineralization.

In the study area, arborescent, stalactitic, stalagmitic and columnar speleothems with horizontal/ascending growth bear evidence of both microbiological and inorganic processes in their genetic phases. Mushroom-shaped speleothems are the most properly classified as microbialites as microbial influence prevailed in their formation processes, while fibrous deposits may correspond to mineral accumulation under the influence of microbial metabolism. However, the rarity of these latter speleothems, found in only one place and in very small number, rendered additional analyses unfeasible. Further investigation is necessary based on new occurrences.

No pattern of speleothem occurrence seems to be related to specific stratigraphic or sedimentary aspects of quartz-sandstones in the study area. However, speleothems tend to develop in sites controlled by stratification and fracturing planes. Such discontinuities favor percolation of water inside rock bodies, thus contributing to the initial weathering, release and removal of ions and molecules from the surface of minerals, a fundamental cycle to the availability of raw material for the development of secondary chemical deposits.

These speleothems, which result from dissolution of quartz grains and kaolinitic cement, are important indicators of karst processes in Furnas Formation and Vila Velha sub-unit quartz-sandstones. The microbial action identified may also have exerted influence on the chemical weathering of mineral components. Corroded quartz grains in altered rocks suggest microbial action, mainly on $\mathrm{pH}$ modifications that render water alkaline setting ideal conditions for chemical weathering of quartz.

The speleothems found in the study area host an abundant diversity of biological, possibly fossil materials capable of preserving paleoecological and paleoenvironmental records of great scientific value. For hosting hundreds of caves and an expressive set of karst features, outcropping areas of the Furnas Formation and Vila Velha Sandstone can be considered a speleological province and a new Brazilian karst region known the Campos Gerais do Paraná one.

\section{ACKNOWLEDGMENTS}

The authors acknowledge the support provided to the Research by Dr. Daniel Atencio of the Laboratory of X-Ray Diffractometry, University of São Paulo, the Laboratory of Sedimentary Petrology Studies, the Laboratory of Minerals and Rocks and the Center of Electron Microscopy of the Federal University of Paraná and the Geology-Research and Multiuser laboratories of the Ponta Grossa State University. In particular, the first author acknowledges the financial support provided to Scientific Project A0016_2015 under his direction by the Boticário Foundation, the doctoral scholarship granted by the Coordination for the Improvement of Higher Education Personnel (CAPES), and the valuable help from the University Group of Speleological Research (GUPE). Sincere thanks to the reviewers for all the indications that resulted in the improvement of this article.

Authorship statement: HSP designed, directed, collected the data, performed the measurements, and wrote the study; LAF, MSM, GBG, and LLM collected and analyzed the data, wrote and revised the manuscript. 


\section{REFERENCES}

Amores, D.R., Warren, L.A., 2009. Metabolic patterning of biosilicification. Chemical Geology, 268 (1-2), 81-88. https://doi.org/10.1016/j.chemgeo.2009.07.013

Araújo, T.P., 2016. Sistema fluvial ou dominado por maré?: estudos de processo de sedimentação e arquitetura deposicional no Canyon do Guartelá, Formação Furnas, Devoniano Inferior, Bacia do Paraná, Brasil. Dissertação de Mestrado. Universidade Estadual de Campinas, Instituto de Geociências, 61 p.

Assine, M.L., Soares, P.C., Milani, E.J., 1994. Seqüências tectono-sedimentares mesopaleozóicas da Bacia do Paraná, sul do Brasil. Revista Brasileira de Geociências, 24 (2), 77-89.

https://doi.org/10.25249/0375-7536.19947789

Assine, M.L., 1996. Aspectos da estratigrafia das seqüências pré-carboniferas da Bacia do Paraná no Brasil. Tese de doutorado. Programa de Pós-Graduação em Geologia Sedimentar, São Paulo, 207 p.

Assine, M.L., 1999. Fácies, icnofósseis, paleocorrentes e sistemas deposicionais da Formação Furnas, no flanco sudeste da bacia do Paraná. Revista Brasileira de Geociências, 29, 357-370.

https://doi.org/10.25249/0375-7536.199929357370

Aubrecht, R., Barrio-Amorós, C.L., Breure, A.S.H., Brewer-Carias, C., Derka, T., Fuentes-Ramos, O.A., Gregor, M., Kodada, J., Kováčik, L., Lánczos, T., Lee, N.M., Liščák, P., Schlögl, J., Šmída, B., Vlček L., 2012. Venezuelan tepuis: their caves and biota. Acta Geologica Slovaca - Monograph, Comenius University, Bratislava, $168 \mathrm{p}$.

Aubrecht, R., Brewer-Carias, C.H., Šmída, B., Audy, M., Kováčik, L', 2008. Anatomy of biologically mediated opal speleothems in the World's largest sandstone cave: Cueva Charles Brewer, Chimantá Plateau, Venezuela. Sedimentary Geology, 203, 181-195.

https://doi.org/10.1016/j.sedgeo.2007.10.005

Auler, A.S., Sauro F., 2019. Quartzite and quartz sandstone caves of South America. In: White, W.B., Culver, D.C., Pipan, T. (Eds.), Encyclopedia of caves. Academic Press, London, p. 850-860. https://doi.org/10.1016/B978-0-12-814124-3.00102-3

Baskar, S., Baskar, R., Kaushik, A., 2007. Evidences for microbial involvement in the genesis of speleothem carbonates, Borra Caves, Visakhapatnam, India. Current Science, 92 (3), 350-355.

https://www.jstor.org/stable/24096731

Bennett, P.C., 1991. Quartz dissolution in an organicrich aqueous system. Geochimica et Cosmochimica Acta, 55, 1781-1797.

https://doi.org/10.1016/0016-7037(91)90023-X

Bergamaschi, S., 1992. Análise Sedimentológica da Formação Furnas na Faixa de Afloramentos do Flanco Norte do Arco Estrutural de Ponta Grossa, Bacia do Paraná. Dissertação de Mestrado, IG-UFRJ, Rio de Janeiro, $172 \mathrm{p}$.

Borghi, L., 1993. Caracterização e análise faciológicas da Formação Furnas (Prídoli Devoniano inferior) em afloramentos do bordo leste da bacia sedimentar do Paraná, Estado do Paraná, Brasil. Dissertação de Mestrado, Instituto de Geociências, Universidade Federal do Rio de Janeiro, Rio de Janeiro, 227 p.

Brehm, U., Gorbushina, A.A., Mottershead, D., 2005. The role of microorganisms and biofilms in the breakdown and dissolution of quartz and glass. Palaeogeography, Palaeoclimatology, Palaeoecology, 219, 117-129. https://doi.org/10.1016/j.palaeo.2004.10.017
Daza Brunet, R., Bustillo Revuelta, M.Á., 2014. Exceptional silica speleothems in a volcanic cave: A unique example of silicification and sub-aquatic opaline stromatolite formation (Terceira, Azores). Sedimentology, 61 (7), 2113-2135. https://doi.org/10.1111/sed.12130

Budny, J.M., 2004. Algunas cuevas en areniscas en Paraná, Brasil. Boletín Informativo de la Comisión de Geospeleología, Federación Espeleológica de América Latina y el Caribe (FEALC), 45 (1), 2-7.

Cañaveras, J.C., Sánchez-Moral, S., Soler, V., SaizJiménez, C., 2001. Microorganisms and microbially induced fabrics in cave walls. Geomicrobiology Journal, 18, 223-240. https://doi.org/10.1080/01490450152467769

Canuto, J.R., Rocha-Campos, A.C., Sato, P.E.S., 1997. The Late Paleozoic Lapa Sandstone (Itarare Subgroup): a possible tunnel-valley fill?. Anais da Academia Brasileira de Ciências, 69 (2), 275-276.

Chan, C.S., Fakra, S.C., Emerson, D., Fleming, E.J., Edwards, K.J., 2011. Lithotrophic iron-oxidizing bacteria produce organic stalks to control mineral growth: implications for biosignature formation. The ISME Journal, 5, 717-727. https://doi.org/10.1038/ismej.2010.173

Corrêa Neto, A.V., Baptista Filho, J., 1997. Espeleogênese em quartzitos da Serra do Ibitipoca, Sudeste de Minas Gerais. Anuário do Instituto de Geociências, 20: 75-87.

Cruz, G.C.F., 2007. Alguns aspectos do clima dos Campos Gerais. In: Melo, M.S., Moro, R.S., Guimarães, G.B. (Eds.), Patrimônio natural dos Campos Gerais do Paraná. Editora UEPG, 230 p.

Dredge, J., Fairchild, I.J., Harrison, R.M., FernandezCortes, A., Sanchez-Moral, S., Jurado, V., Gunn, J., Smith, A., Spötl, C., Mattey, M., Wynn, P.M., Grassineau, N., 2013. Cave aerosols: distribution and contribution to speleothem geochemistry. Quaternary Science Reviews, 63, 23-41. https://doi.org/10.1038/ismej.2010.173

Dubois, C., Quinif, Y., Baele, J-M., Barriquand, L., Bini, A., Bruxelles, L., Dandurand, G., Havron, C., Kaufmann, O., Lans, B., Maire, R., Martin, J., Rodet, J., Rowberry, M.D., Tognini, P., Vergari, A., 2014. The process of ghost-rock karstification and its role in the formation of cave systems. Earth-Science Reviews, 131, 116-148.

https://doi.org/10.1016/j.earscirev.2014.01.006

Ehrlich, H.L., 1996. Geomicrobiology (3 ${ }^{\text {rd }}$ Ed.). Marcel Dekker, New York, 719 p.

Fernández Verdia, M.Á., Sanjurjo Sánchez, J., Vidal Romaní, J.R., 2000. Génesis de espeleotemas de ópalo-a en sistemas cársticos desarrollados en rocas ácidas. Cadernos Laboratorio Xeolóxico de Laxe Coruña, 25, 353-356.

Finlayson, B.L., Webb, J.A., 1985. Amorphous speleothems. Cave Science, 12, 3-8.

Flügel Filho, J.C., Guimarães, G.B., Pontes, H.S., Massuqueto, L.L., Melo, M.S., 2012. Geodiversidade dos Campos Gerais do Paraná: morfologia de espeleotemas de cavidades em arenitos da Formação Furnas. Proceedings of $46^{\circ}$ Congresso Brasileiro de Geologia. Santos-SP. Sociedade Brasileira de Geologia.

Flügel Filho, J.C., 2012. Geossítio Sumidouro Córrego das Fendas, Ponta Grossa (PR): geodiversidade cárstica de um sistema subterrâneo e seus valores. Monografia Departamento de Geociências, Universidade Estadual de Ponta Grossa.

Forti, P., 2001. Biogenic speleothems: an overview. International Journal of Speleology, 30, 39-56. https://doi.org/10.5038/1827-806X.30.1.4 
França, A.B., Potter, P.E., 1988. Estratigrafia, ambiente deposicional e análise de reservatórios do Grupo Itararé (Permocarbonífero), Bacia do Paraná (Parte I). Boletim de Geociências da PETROBRÁS, 2, 147-191.

França, A.B., Winter, W.R., Assine, M.L., 1996. Arenitos Lapa-Vila Velha: um modelo de trato de sistemas subaquosos canallobos sob influência glacial, Grupo Itararé (C-P), Bacia do Paraná. Revista Brasileira de Geociências, 26 (1), 43-56. https:// doi.org/10.25249/0375-7536.19964356

Galan, C, Lagarde, J., 1988. Morphologie et evolution des caverns et formes superficielles dans les quartzites du Roraima (Venezuela). Karstologia, 11 (12), 49-60. https://doi.org/10.3406/karst.1988.2190

Gonzalez-Pimentel, J.L., Miller, A.Z., Jurado, V., Laiz, L., Pereira, M.F.C., Saiz-Jimenez, C., 2018. Yellow coloured mats from lava tubes of La Palma (Canary Islands, Spain) are dominated by metabolically active Actinobacteria. Scientific Reports, 8 (1), 1-11. https://doi.org/10.1038/s41598-018-20393-2

Hallberg, R., Ferris, F.G., 2004. Biomineralization by Gallionella. Geomicrobiology Journal, 21 (5), 325-330. https://doi.org/10.1080/01490450490454001

Hardt, R., Rodet, J., Pinto, S.A.F., Willems, L., 2009. Exemplos brasileiros de carste em arenito: Chapada dos Guimarães (MT) e Serra de Itaqueri (SP). SBE Campinas, SP. Espeleo-Tema, 20 (1/2), 7-23.

Hardt, R., 2011. Da carstificação em arenitos. Aproximação com o suporte de geotecnologias. Tese de doutorado, Universidade Estadual Paulista - Instituto de Geociências e Ciências Exatas, 224 p.

Hill, C.A., Forti, P., 1997. Cave minerals of the world $\left(2^{\text {nd }}\right.$ Ed.). National Speleological Society, Huntsville, AL, 463 p.

Iespa, A.A.C., Iespa, C.M.D., Borghi, L., 2012. Evolução paleoambiental da Lagoa Salgada utilizando microbialitos, com ênfase em microfácies carbonáticas. Geociências (São Paulo), 31 (3), 371-380.

Klimchouck, A.B., Nasedkin, V.M., Cunningham, K.I., 1997. Speleothems of aerosol origin: reply. Journal of Caves and Karst Studies, 59, 45-47.

Letenski, R., Guimarães, G.B., Piekarz, G.F., Melo, M.S., 2009 - Geoturismo no Parque Estadual de Vila Velha: nas trilhas da dissolução. Pesquisas em Turismo e Paisagens Cársticas, 2 (1), 5-15.

Lestenski R., Melo M.S., Guimarães G.B., Piekarz G.F., 2011 - Geoturismo no Parque Estadual de Vila Velha: nas trilhas da dissolução. In: Carpanezzi, O.T.B. \& CAMPOS, J.B. (Eds.), Coletânea de pesquisas: Parque Estaduais de Vila Velha, Cerrado e Guartelá, 239-248.

Lobato, G., Borghi L., 2005. Análise estratigráfica da Formação Furnas (Devoniano Inferior) em afloramentos da borda leste da Bacia do Paraná. In: Anais do Congresso Brasileiro de P\&D em Petróleo e Gás, 3, Salvador, p. 1-6.

Lundberg, J., Brewer-Carias, C., McFarlane, D.A., 2010. Preliminary results from U-Th dating of glacialinterglacial deposition cycles in a silica speleothem from Venezuela. Quaternary Research, 74 (1), 113-120. https://doi.org/10.1016/j.yqres.2010.03.005

Lundberg, J., Brewer-Carías, C., McFarlane, D.A., 2018. On biospeleothems from a Venezuelan tepui cave: U-Th dating, growth rates, and morphology. International Journal of Speleology, 47, 361-378. https://doi.org/10.5038/1827-806X.47.3.2212

Maack R., 1946. Geologia e geografia da região de Vila Velha e considerações sobre a glaciação carbonifera do Brasil. Curitiba, Arquivos do Museu Paranaense, 305 p.

Maltsev, V.A., 1997. Speleothems of aerosol origin: Discussion. Journal of Caves and Karst Studies, 59, 43-44.
Massuqueto, L.L., 2010. O sistema cárstico do Sumidouro do Rio Quebra-Perna (Ponta Grossa - PR): caracterização da geodiversidade e de seus valores. Monografia, Departamento de Geociências, Universidade Estadual de Ponta Grossa, 81 p.

Melo, M.S., Coimbra A.M., 1996. Ruiniform relief in sandstones - the example of Vila Velha, Carboniferous of the Paraná Basin, Southern Brazil. Barcelona, Acta Geológica Hispanica, 31 (4), 25-40.

Melo, M.S., 2006. Formas rochosas do Parque Estadual de Vila Velha. Ponta Grossa: Editora UEPG, 145 p.

Melo, M.S., Bosetti, E.P., Godoy, L.C., Pilatti, F., 2007. Vila Velha, PR: Impressionante relevo ruiniforme. In: Schobbenhaus, C., Campos, D.A., Queiroz, E.T., Winge, M., Berbert-Born, M. (Eds.), Sítios geológicos e paleontológicos do Brasil, p. 269-277.

Melo, M.S., Giannini P.C.F., 2007. Sandstone dissolution landforms in the Furnas Formation, Southern Brazil. Earth Surface Processes and Landforms, 32, 21492164. https://doi.org/10.1002/esp.1520

Melo, M.S., 2010. Processos erosivos superficiais e subterrâneos em arenitos da Formação Furnas na região dos Campos Gerais do Paraná. Relatório Resumido. CNPq - Conselho Nacional de Desenvolvimento Científico e Tecnológico, 20 p.

Melo, M.S., Guimarães, G.B., Pontes, H.S., Massuqueto, L.L., Pigurim, I., Bagatim, H.Q., Giannini, P.C.F., 2011. Carste em rochas não-carbonáticas: o exemplo dos arenitos da Formação Furnas, Campos Gerais do Paraná/Brasil e as implicações para a região. SBE Campinas, SP. Espeleo-Tema, 22 (1), 81-97.

Melo, M.S., Guimarães, G.B., Chinelatto, A.L., Giannini, P.C., Pontes, H.S., Chinelatto, A.C.A., Atencio, D., 2015. Kaolinite, illite and quartz dissolution in the karstification of Paleozoic sandstones of the Furnas Formation, Parana Basin, Southern Brazil. Journal of South American Earth Sciences, 63, 20-35. https://doi.org/10.1016/j.jsames.2015.06.011

Milani, É.J., França, A.B., Schneider, R.L., 1994 - Bacia do Paraná. Boletim de Geociências Petrobras, 8: 69-82.

Milani, E.J., Melo, J.H.G., Souza, P.A., Fernandes, L.A.E, França, A.B., 2007. Bacia do Paraná. Boletim de Geociências da Petrobras, Rio de Janeiro, 15 (2), 265-287.

Miller, A.Z., Pereira, M.F.C., Calaforra, J.M., Forti, P., Dionísio, A., Saiz-Jimenez, C., 2014. Siliceous speleothems and associated microbe-mineral interactions from Ana Heva Lava Tube in Easter Island (Chile). Geomicrobiology Journal, 31 (3), 236-245. https://doi.org/10.1080/01490451.2013.827762

Miot, J., Benzerara, K., Kappler, A., 2014. Investigating microbe-mineral interactions: Recent advances in X-ray and electron microscopy and redox-sensitive methods. Annual Review of Earth and Planetary Sciences, 42, 271-289.

https://doi.org/10.1146/annurev-earth-050212-124110

Morais, F., Souza, L.B., 2009. Cavernas em arenito na porção Setentrional da Serra do Lajeado Estado do Tocantins, Brasil. Revista de Biologia e Ciências da Terra, 9 (2), 1-13.

Pavan, B.H., 2015. Sistemas fluviais de grandes dimensões: uma reinterpretação da Formação Furnas no Cânion Guartelá-PR. Monografia, Geologia na Universidade Estadual de Campinas, $45 \mathrm{p}$.

Pontes, H.S., Rocha, H.L., Massuqueto, L.L., Melo, M.S., Lopes, M.C., Guimarães, G.B., 2008. Mudanças recentes na circulação subterrânea do Rio QuebraPedra (furna do Buraco do Padre, Ponta Grossa, PR). Proceedings of $44^{\circ}$ Congresso Brasileiro de Geologia. 
Pontes, H.S., 2010. Caverna da Chaminé, Ponta Grossa, Paraná. Exemplo de Relevo Cárstico na Formação Furnas. Monografia (Graduação em Bacharelado em Geografia) - Setor de Ciências Exatas e Naturais UEPG, 92 p.

Pontes, H.S., Massuqueto, L.L., Budny, J.M, 2012. Gruta Cambiju: importante geossitio nos arenitos da Formação Furnas, Município de Ponta Grossa, Campos Gerais do Paraná. Proceedings of $46^{\circ}$ Congresso Brasileiro de Geologia.

Pontes, H.S., 2014. Espacialização de feições cársticas da Formação Furnas: ferramenta para gestão do território no Município de Ponta Grossa (PR). Dissertação de Mestrado, Programa de Pós-graduação em Geografia, Universidade Estadual de Ponta Grossa, 163 p.

Pontes, H.S., Massuqueto, L.L., Guimarães, G.B., Mochiutti, N.F.B., 2017. Patrimônio espeleológico do município de Tibagi, Campos Gerais do Paraná. In: Rasteiro, M.A., Teixeira-Silva, C.M., Lacerda, S.G. (Eds.), Proceedings of Congresso Brasileiro de Espeleologia, 34. Ouro Preto. Campinas: SBE, 417-426.

Pontes, H.S., Massuqueto, L.L., Foltran, A.C., Pontes, F.S., Guimarães, G.B., Mochiutti, N.F.B., Guimarães, S.K., Burgardt, S., do Vale, T.F., Feitosa, N.M.N., 2018a. Patrimônio espeleológico do Parque Nacional dos Campos Gerais: Ações prioritárias para o manejo e propostas de ampliações da Unidade de Conservação. Grupo Universitário de Pesquisas Espeleológicas GUPE - Ponta Grossa, 61 p.

Pontes, H.S., Massuqueto, L.L., Fernandes, L.A., Foltran, A.C., Melo, M.S., Moreira, J.C., 2018b. Caves geodiversity evaluation as an instrument to the management of the Campos Gerais National Park, Southern Brazil. Geoheritage, 10 (1), 1-11. https://doi.org/10.1007/s12371-018-0317-9

Renó, R., Duque T.R.F., Lucon, T.N., Levy, M.O.P., Simões, P.R., 2009. Considerações sobre o carste em quartzito do Parque Estadual do Itacolomi, Mariana/ Puro Preto - MG. Proceedings of XXX Congresso Brasileiro de Espeleologia. Montes Claros MG, 09-12 de julho de 2009 - Sociedade Brasileira de Espeleologia, p. 193-196.

Riechelmann, D.F.C., Fohlmeister, J., Tjallingii, R., Jochum, K.P., Richter, D.K., Brummer, G.J.A., Scholz, D., 2016. Detection and origin of different types of annual laminae in recent stalagmites from Zoolithencave, southern Germany: Evaluation of the potential for quantitative reconstruction of past precipitation variability. Climate of the Past Discussion, 1-42. https://doi.org/10.5194/cp-2016-18

Sallstedt, T., Ivarsson, M., Lundberg, J., Sjöberg, R., Vidal Romaní, J.R., 2014. Speleothem and biofilm formation in a granite/dolerite cave, Northern Sweden. International Journal of Speleology, 43, 305-313. https://doi.org/10.5038/1827-806X.43.3.7

Sauro, F., 2014. Structural and lithological guidance on speleogenesis in quartz-sandstone: Evidence of the arenisation process. Geomorphology, 226, 106-123. https://doi.org/10.1016/j.geomorph.2014.07.033

Sauro, F., Tisato, N., De Waele, J., Bernasconi, S.M., Bontognali T.R.R., Galli E., 2014. Source and genesis of sulphate and phosphate-sulphate minerals in a quartzsandstone cave environment. Sedimentology, 61 (5), 1433-1451. https://doi.org/10.1111/sed.12103

Sauro, F., Cappelletti, M., Ghezzi, D., Columbu, A., Hong, P., Zowawi, H.M., Carbone, C., Piccini, L., Vergara, F., Zannoni, D., Waele, J.D., 2018. Microbial diversity and biosignatures of amorphous silica deposits in orthoquartzite caves. Scientific Reports, 8, 17569.

https://doi.org/10.1038/s41598-018-35532-y
Sauro, F., Mecchia, M., Piccini, L., De Waele, J., Carbone, C., Columbu, A., Pisani, L., Vergara, F., 2019. Genesis of giant sinkholes and caves in the quartz sandstone of Sarisariñama tepui, Venezuela. Geomorphology, 342, 223-238.

https://doi.org/10.1016/j.geomorph.2019.06.017

Schneider, R.L., Muhlmann, H., Tommasi, E., Medeiros, R.A., Daemon, R.F., Nogueira, A.A., 1974. Revisão estratigráfica da Bacia do Paraná. Proceedings of Congresso Brasileiro de Geologia, 28. Porto Alegre, 1, 41-65.

Søgaard, E.G., Aruna, R., Abraham-Peskir, J., Koch, C.B., 2001. Conditions for biological precipitation of iron by Gallionella ferruginea in a slightly polluted ground water. Applied Geochemistry, 16 (9-10), 11291137. https://doi.org/10.1016/S0883-2927(01)00014-2

Spinardi, R.D., Lopes, M.C., 1990. Levantamento espeleológico da caverna das Andorinhas - PR 052. Proceedings of IV Seminário de Pesquisa. Guarapuava, UNICENTRO, p. 39-40.

Urbani, F., 1990. Algunos comentários sobre terminolgia karrstica aplicada a rocas siliceas. Boletín de la Sociedad Venezolana de Espeleologia, 24, 5-6.

Vesely, F.F., 2011. Sulcos de origem glacial em arenitos neocarboniferos do Parque Estadual de Vila Velha, sudeste do Paraná. Geociências, 30, 589-599.

Vidal Romaní, J.R., Rodriguez, M.V., 2007. Types of granite cavities and associated speleothems: genesis and evolution. Nature Conservation, 63, 41-46.

Vidal Romaní, J.R., Sanjurjo Sánchez, J., Vaqueiro M., Fernández Mosquera D., 2010. Speleothems of granite caves. Comunicações Geológicas, 97, 71-80.

Vidal Romaní, J.R., Vaqueiro Rodríguez, M., Sanjurjo Sánchez, J., González López, L. 2014. Morphologic types of speleothems in magmatic rock caves. Proceedings of Reunión Nacional de Geomorfología, Cáceres, 490-493.

Webb, J.A., Finlayson, B.L., 1984. Allophane and opal speleothems from granite caves in south-east Queensland. Australian Journal of Earth Science, 31, 341-349. https://doi.org/10.1080/14400958408527935

White, W.R., Jefferson, G.L., Haman, J.F., 1966. Quartzite karst in southeastern Venezuela. Speleology, 2, 309314. https://doi.org/10.5038/1827-806X.2.4.1

Willems, L., Rodet, J., Pouclet, A., Melo, S., Rodet, M.J., Compère, P.H., Hatert, F., Auler, A.S., 2008. Karsts in sandstones and quartzites of Minas Gerais, Brazil. Cadernos Lab. Xeolóxico de Laxe, 33, 127-138.

Wray, R.A.L., 1999. Opal and chalcedony speleothems on quartz sandstones in the Sydney region, southeastern Australia. Australian Journal of Earth Sciences, 46 (4), 623-632.

https://doi.org/10.1046/j.1440-0952.1999.00732.x

Wray, R.A.L., Sauro, F., 2017. An updated global review of solutional weathering processes and forms in quartz sandstones and quartzites. Earth-Science Reviews, 171, 520-557. https://doi.org/10.1016/j.earscirev.2017.06.008

Zalán, P.V., Wolff, S., Conceição, J.C.D.J., Vieira, I.S., Astolfi, M.A.M., 1987. A divisão tripartite do Siluriano da Bacia do Paraná. Revista Brasileira de Geociências, 17 (3), 242-252. https://doi.org/10.25249/0375-7536.1987242252

Zalán, P.V., Wolff, S., Conceição, J.C.J., Marques, A., Astolfi, M.A.M., Vieira, I.S., Appi, V.T., Zanotto, O.A., 1990. Bacia do Paraná. In: Gabaglia, G.P.R., Milani, E.J. (Eds.), Origem e evolução de Bacias Sedimentares ( $2^{\text {nd }}$ Ed.). Rio de Janeiro: Gávea, Cap, Bacia do Paraná, p. $135-168$. 
Zepeda Mendoza, M.L., Lundberg, J., Ivarsson, M., Campos, P., Nylander, J.A.A., Sallstedt, T., Dalen, L., 2016. Metagenomic analysis from the interior of a speleothem in Tjuv-Ante's Cave, Northern Sweden. PLoS ONE, 11 (3), e0151577.

https://doi.org/10.1371/journal.pone.0151577
Zhilei, S., Jun, L., Zhixue, S., Wei, H., Ruyong, C., Jiwei, L., 2010. Formation mechanism of biogenic Fe-Si oxide deposits in seafloor hydrothermal systems. Advances in Earth Science, 25 (12), 1325-1336. 